\title{
At the Periphery of Nanyang: The Hakka Community of Timor-Leste
}

\author{
Juliette Huber
}

A story by an East Timorese elder, recounting the origin of his clan, includes the following lines:

My ancestor came by sea on a ship. A Chinese captain brought him here. My ancestor came to Irabere on a Chinese ship.

I recorded this story in 2013 among the Makalero people, who live in the remote Iliomar subdistrict on the south-eastern coast of Timor-Leste. Clan origin stories are of great ritual significance for the Makalero, and the fact that a Chinese captain is featured in this narrative illustrates the degree to which the ethnic Chinese are an established part of the East Timorese scene. They started to settle on the island during the Portuguese colonial period, and by 1975 a vibrant community existed. Today, the majority of Chinese-Timorese live abroad, having fled East Timor during the Indonesian occupation between 1975 and $1999 .{ }^{1}$

Despite its long history, the Chinese community of Timor-Leste has largely been neglected in the broader literature on Chinese-descended communities worldwide. The scholarship on Chinese communities in Southeast Asia routinely discusses communities in Burma (Myanmar), Cambodia, Indonesia, Laos, Malaysia, the Philippines, Singapore, Thailand, Vietnam and Brunei,

1 In this contribution, the term "Chinese-Timorese" is used to refer to the ethnic Chinese population of East Timor only. The ethnic Chinese population of Indonesian West Timor is not discussed. In Timor-Leste, Chinese-Timorese are referred to, and refer to themselves, as Cina Timor in Tetun, the local lingua franca (mostly using the Indonesian spelling Cina rather than Tetun Xina in writing), or Comunidade Chinesa Timorense in Portuguese (cf. Kammen \& Chen 2019: 165, fn 1). Furthermore, I use "East Timor" to refer to the territory occupied today by Timor-Leste without reference to a particular historical period. It thus covers colonial-era Portuguese Timor, the Indonesian province of East Timor (Timor Timur; 1975-99) and independent Timor-Leste. The nomenclature used in the discussion of specific historical periods may differ. 
but makes no mention of Timor-Leste. ${ }^{2}$ In recent years, however, this small community has garnered somewhat more attention, having been the focus of a small number of publications aimed at academic audiences (Kammen \& Chen 2019; Soares 2019; Gunn 2016; Berlie 2015; Pinto 2015; Pinto 2014; Chew \& Huang 2014) on the one hand, and the general public on the other (Mulyanto 2019; Raynor 2019; England 2001; England 1999).

The aims of this chapter are twofold. As part of the present collection, it intends to increase the visibility of the Chinese-Timorese community in the broader literature on Chinese-descended people worldwide. Secondly, it will give a first preliminary account of the endangered Hakka variety spoken by that community, thus contributing to our knowledge of the properties of Hakka varieties in Southeast Asia. The chapter is organized as follows: section 2 provides background on Hakka, East Timor, and the historical links between Timor and Macao, the point of departure for many Chinese immigrants to East Timor. Section 3 outlines the history of the Chinese-Timorese community from the colonial period to the present day. Section 4 discusses the Hakka variety of Timor-Leste, drawing attention to its endangered status and highlighting some characteristic features. The final part includes a brief summary and conclusion.

\section{$2 \quad$ Background}

One characteristic of the Chinese community of Timor-Leste is its "Hakkadominant homogeneity" (Berlie 2015: 38). I will therefore briefly introduce the Hakka people and their language. Afterwards, I provide information on East Timor, its history as well as the linguistic scene of the country. Finally, I focus on the historical relations between East Timor and Macao as Portuguese possessions during the colonial period.

\subsection{Hakka}

The term Hakka refers to a Sinitic language of southern China as well as its speakers, whose number is estimated to be somewhere around 40 million (Lau 2017; Chappell 2015: 15). The Hakka heartland is located at the intersection

2 See e.g. Pan (1999), Rae \& Witzel (2008), and Tan (2013). Exceptions are Purcell (1966: 3), which briefly mentions Portuguese Timor in a table summarizing the number of ethnic Chinese in various countries of Southeast Asia; and Wurm et al.'s (1987) Language Atlas of China, which shows a Hakka-speaking Chinese community in East Timor on Map B $16 \mathrm{~b}$ of "Overseas Chinese" communities worldwide. Neither work provides further information. 
of the Guangdong, Guangxi, Fujian, and Jiangxi provinces (Skinner 1967: 102; Leong 1997: 23-25), in areas made up of remote, resource-poor highlands. Historically, these tended to be frontier regions which other Chinese avoided, and the Hakka's socio-economic status was low compared to other groups living in the same regions. This resulted in a high degree of geographic mobility: the Hakka are "sojourners and migrants par excellence, rarely hesitating to pull up stakes and move on to another destination, whether within or outside China" (Pan 1998: 26) and "most willing among all the Chinese migrant groups to go into the rural areas" (Wang 2003: 58). Indeed, according to Wang (2003: 222), "where the migrants need to be adventurous and act as pioneers entering undeveloped areas, the Hakka had an edge over everybody else". Outside of mainland China, Hakka speakers are widespread particularly in Taiwan and parts of Southeast Asia (cf. Wurm et al. 1987, Map B 16b). Small communities are also found across the globe, e.g. in Mauritius (Lefort 2018) and in Suriname (Fat 2015). Wang (2003: 219) notes that even overseas, the Hakka tend to "not [be] the majority where there are large concentrations of Chinese people", but "a minority among Chinese minorities", although they are the majority in some countries with relatively small Chinese populations, such as Timor-Leste or Mauritius. Even in large countries where they are a minority, the Hakka may regionally be a majority. For instance, they are estimated to make up less than $20 \%$ of Chinese-Indonesians (Lim \& Mead 2011: 19). On the Indonesian island of Belitung, however, they accounted for over $70 \%$ of the total population in 1930 (Heidhues 1996:176), and they presumably make up a large proportion of the island's population to the present day. Possibly because of their mobility, the Hakka are reported to be "unmatched in the extent of their cultural deviance, [...] stubborn resistance to assimilation, and ethnic self-consciousness" (Leong 1997: 19).

According to orthodox Hakka historiography, the Hakka migrated south from the Central Plain beginning about $300 \mathrm{CE}$ and arrived at their current locations in a series of five migration waves (Luo 1933). This account is intended to cement their status as "true Han Chinese from the cradle of Chinese civilization", but is "ethnic rhetoric" rather than pure scholarship (Leong 1997: 29). While a southward migration from the Yellow River Basin towards the modern provinces of Guangdong, Guangxi, Fujian, and Jiangxi did take place (Norman 1988: 181-85), this population movement preceded the split of what Norman (1988) calls Old Southern Chinese into Min, Hakka and Yue (Cantonese). The differentiation of Hakka from those groups "can presumably be dated at least from the Song" (Leong 1997: 33), i.e. between the tenth and the thirteenth centuries CE. Similar dates can be assumed for the settlement of the Hakka heartland. The name Hakka, as well as a sense of Hakka identity, however, 
are much younger. The term Hakka derives from Cantonese $\mathrm{haak}^{3} \mathrm{gaa} \mathrm{a}^{3}$ (客家) 'guest families', and Constable (1996) and Leong (1997) suggest that a Hakka identity was constructed after 1800 , in the wake of territorial conflicts with Cantonese-speaking residents of Guangdong (cf. Sagart \& Chappell 2011). Prior to this period, a variety of localized and context-specific designations were used to refer to Hakka-speaking groups by both outsiders as well as Hakka speakers themselves (cf. Leong 1997: 47, 65-67). Lau (2017) reports that as late as the 1980 s there were Hakka speakers in China who were either ignorant of the term Hakka or denied their membership to this group, showing that the construction of the Hakka identity was a lengthy process.

Linguistically, various local dialects of Hakka can be distinguished. Wurm et al. (1987) counts eight subdialects, whereas Lau (2017) identifies four. There are conflicting reports regarding the extent of the differences between them: Norman (2003: 72), for instance, argues that in Hakka as well as other Sinitic languages differences between individual dialects are "in many cases considerable" (cf. Lau 2017). According to Sagart \& Chappell (2011), on the other hand, Hakka dialects are remarkably homogeneous (cf. Wurm et al. 1987). What this apparent contradiction seems to boil down to is what individual scholars label as Hakka dialects, a question which is far from trivial: Sagart (1998) points out numerous problems in delimiting Hakka from Gan, and concludes that " $[\mathrm{m}]$ ost accounts of the geographical extent of the Hakka dialect rely, implicitly, on Hakka self-awareness, rather than on some linguistic feature" (Sagart 1998: 297). The Meixian (梅縣; or Moyen, Moi-yan) dialect of Hakka is considered the most representative of Hakka dialects and is generally taken as a de facto standard. Meixian city, in the northeast of Guangdong, is considered the cultural capital of the Hakka (Sagart \& Chappell 2011), and according to Lau (2017), the dialect spoken there can be understood by most Hakka speakers.

\subsection{East Timor}

Timor-Leste (officially the Democratic Republic of Timor-Leste; also known as East Timor) is a sovereign state which occupies the eastern half of the island of Timor as well as the Oecussi enclave in the western part of the island. Fig. 2.1 shows its location within the Indonesian archipelago. With a surface of just over 15,00o km² (Government of Timor-Leste) and a population of 1.3 million (UNESCo Bangkok: Asia and Pacific Regional Bureau for Education 2018), it is one of the youngest nations in the world, having gained independence from Indonesia in 2002.

Timor-Leste's capital, Dili, is the country's main urban centre, with a population of 300,000; this is followed by Baucau with approximately 125,000 


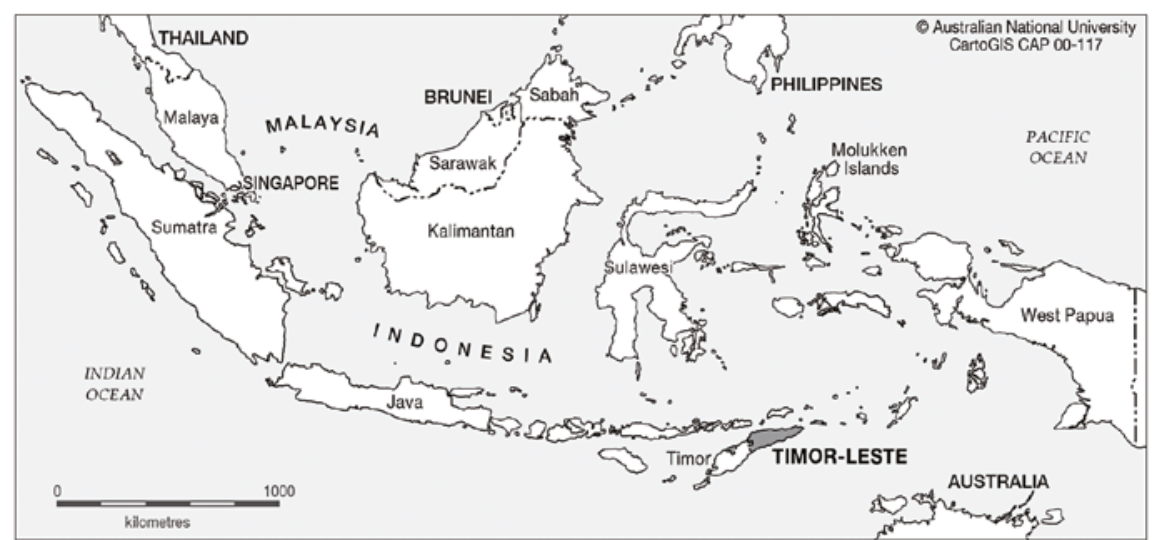

FIGURE 2.1 Timor-Leste in relation to its closest neighbours

CARTOGIS SCHOLARLY INFORMATION SERVICES, THE AUSTRALIAN NATIONAL UNIVERSITY, LICENSE UNDER A CREATIVE COMMONS BY-SA; DOWNLOADABLE FROM HTTP://ASIAPACIFIC.ANU.EDU.AU/MAPSONLINE/ BASE-MAPS/TIMOR-LESTE-2; FULL REFERENCE: CARTOGIS SERVICES. THE POSITION OF TIMOR-LESTE IN RELATION TO ITS CLOSEST NEIGHBOURS. CANBERRA: COLLEGE OF ASIA AND THE PACIFIC, THE AUSTRALIAN NATIONAL UNIVERSITY. HTTP://ASIAPACIFIC .ANU.EDU.AU/MAPSONLINE/ (29 JULY, 2019)

inhabitants (General Directorate of Statistics). Fig. 2.2 shows the provinces and towns of Timor-Leste. Over $69 \%$ of Timor-Leste's population lives in rural areas (UNEsco Bangkok: Asia and Pacific Regional Bureau for Education 2018).

Following Hajek (2000: 213), East Timor's history since Western contact can be divided into three discrete periods:

(1) Portuguese contact and colonization (150os-1975)

(2) Indonesian occupation (1975-99)

(3) Post-Referendum/Independence (1999/2002-present)

The Portuguese arrived in the Lesser Sunda Islands in the early sixteenth century, establishing themselves on the islands of Solor, Ende, Timor, and Flores (Subrahmanyam 2012: 219; Figueiredo 2004: 113). Attracted to Timor by its rich supply of sandalwood, they initially traded the precious commodity via their base on Solor (see Fig. 2.2 below). Towards the end of the sixteenth century, they started establishing permanent settlements on Timor's north coast, and the island was officially declared a Portuguese colony in 1702 (Sousa 2006: 15).

Around the turn of the sixteenth and seventeenth century, the Dutch East India Company (Voc) began to challenge Portuguese dominance in the area, capturing important Portuguese bases like Ambon and Melaka (Hägerdal 2012: 34-35). The Portuguese-Dutch rivalry arrived in the Timor area in the 


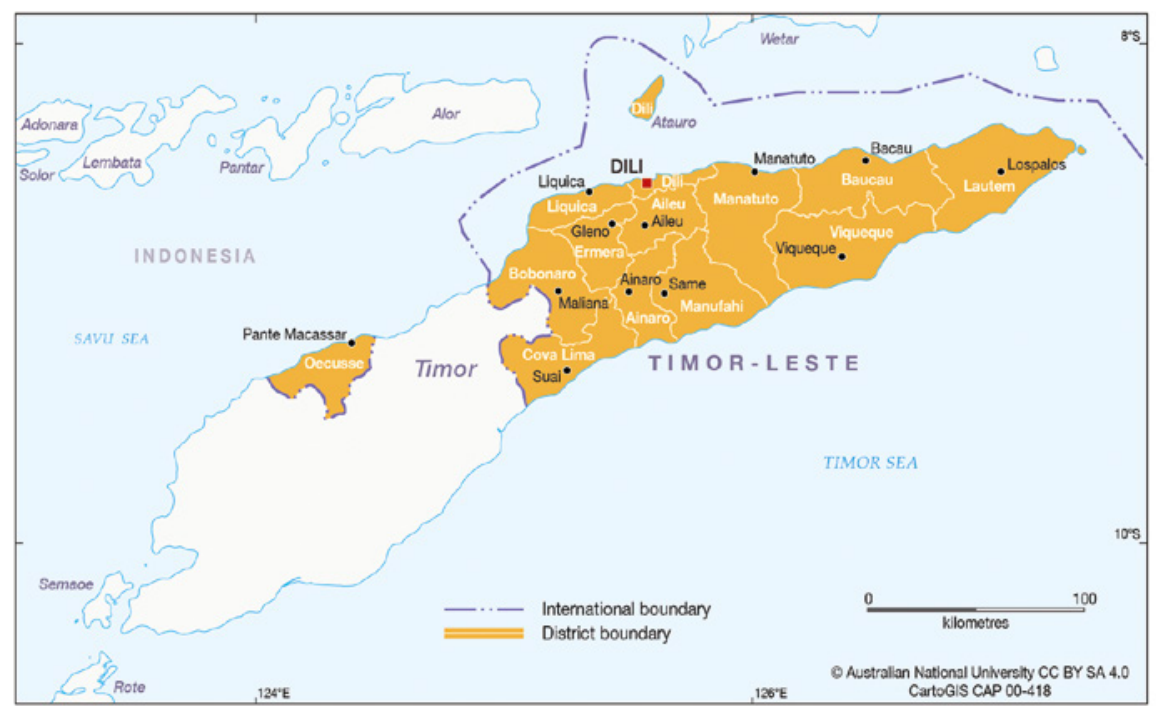

FIGURE 2.2 Map of Timor-Leste

CARTOGIS SCHOLARLY INFORMATION SERVICES, THE AUSTRALIAN NATIONAL UNIVERSITY, LICENSE BY-SA LICENSE; DOWNLOADABLE FROM HTTP://

ASIAPACIFIC.ANU.EDU.AU/MAPSONLINE/BASE-MAPS/TIMOR-TIMOR-LESTE

mid-seventeenth century and dominated the colonial history of Timor up until the nineteenth century. It was finally concluded in 1859 , when the Dutch and the Portuguese agreed on a border between their respective territories on Timor in the Treaty of Lisbon, and Portugal formally ceded claims to Solor and other nearby islands to the Netherlands (Treaty of Lisbon 1861; cf. Gunn 1999: 75). The land border between the modern states of Indonesia and Timor-Leste largely conforms to the division established in this treaty.

East Timor remained a Portuguese colony until 1975, with the dubious distinction of being "the most backward of the Western colonies in Asia" (Kammen \& Chen 2019: 7). Portuguese control over the mountainous interior of the island was tenuous up until the early twentieth century and was consolidated only after several rebellions and subsequent pacification campaigns (Gunn 1999: 82-101). The colony was also used as a "dumping ground for subversives" (Moutinho 2004: 80), including both political exiles and ordinary criminals (Gunn 1999: 114). More detailed information on the colonial history of East Timor can be found in Hägerdal (2012), Subrahmanyam (2012), and Gunn (1999).

In 1975, East Timor declared independence from Portugal and was promptly invaded by Indonesia, which had stoked and exploited fears of communist tendencies in the leading Fretilin (Frente Revolucionaria do Timor Leste 
Independente) party (see Gunn 1999: 147-54; Thaler 2012: 211). East Timorese forces fought the invasion with some success in the first few years but were ultimately overwhelmed by Indonesia's military superiority. Nonetheless, small guerrilla forces remained active throughout the 24-year occupation, which, according to Durand (2011), was "one of the greatest human tragedies of the second half of the twentieth century". It is estimated that $20 \%-30 \%$ of East Timor's population had died by 1999 (Durand 2011; cf. Kiernan 2003). In 1999, Indonesia allowed the East Timorese to hold a referendum in order to decide between autonomy within Indonesia or independence. When a clear majority (78.5\%) voted in favour of independence (KPP HAM 2006: 37), pro-Indonesian militia retaliated, causing more than a thousand deaths, the displacement of hundreds of thousands and the near-total destruction of the country's infrastructure (Babo Soares 2003: 70; KPP HAM 2006: 54). In 2002, independence was finally achieved under the direction of the United Nations, who remained in the country until 2012 (Martin \& Mayer-Rieckh 2005; United Nations 2019). The situation in Timor-Leste has since been fairly stable, apart from a period of unrest from 2006 to 2007 (Scambary 2009). The country is, however, still very much dependent on foreign investment and aid (The Heritage Foundation 2019).

Timor-Leste has two co-official languages, the indigenous lingua franca Tetun Dili and Portuguese. The country is characterized by considerable linguistic diversity, with some 20 Austronesian and Papuan (Timor-Alor-Pantar) languages being spoken according to Glottolog (Hammarström et al. 2019). ${ }^{3}$ Neither a number nor individual language names apart from Tetun and Portuguese are given in Timor-Leste's Constitution, ${ }^{4}$ which merely states that "Tetu[n] and the other national languages shall be valued and developed by the State". In the linguistic literature on Timor-Leste, Hakka generally goes unmentioned; exceptions are, to my knowledge, only Hull (2002) and Hajek (2000). Hajek (2000) is a brief language history of East Timor which includes

3 Different counts are found in other sources: for instance, up until approximately 2010 Timor-Leste's Instituto Nacional de Linguística gave the number of indigenous languages as 16 (cf. Hull 2002). The most recent edition of Ethnologue (Eberhard, Simons \& Fennig 2019) lists 21 languages, and Edwards \& U B B's (2018) linguistic map of Timor shows 26 languages spoken in Timor-Leste. The differences are mostly due to different decisions on what is to be counted as a separate language and what as a dialect of another language. Ethnologue and Glottolog furthermore include an extinct Portuguese-based creole (Bidau Creole Portuguese), and Ethnologue adds Portuguese, which, despite its status as an official language, is not commonly used in everyday life.

4 Downloadable from http://timor-leste.gov.tl/?cat=37\&lang=en. 
a paragraph on the Chinese minority (2000: 218), but does not give any linguistic information. Hull (2002), formerly the director of the Instituto Nacional de Linguística, gives very basic information on the 16 indigenous languages of Timor-Leste and, presumably in order to illustrate relatedness, provides the numerals from one to ten in each language. He also includes a paragraph on the non-indigenous languages of the island, where two lines are devoted to Hakka. Both sources appeared at a time when Timor-Leste had gained worldwide attention thanks to the 1999 referendum, when little was known about its languages. Much progress has since been made in the description of Timor's indigenous languages. Our knowledge of Timor-Hakka, however, remains as rudimentary as it ever was.

\subsection{The Portuguese in Asia: Timor and Macao}

As Portugal's influence in Asia diminished, increasingly close ties developed between the Portuguese territories in the Lesser Sunda Islands - Timor, Solor, and a few nearby islands - and Macao, Portugal's other Far Eastern possession. The Portuguese had established a trading post, which rapidly developed into an important centre of commerce, in Macao in 1557. Of particular importance was the silk and silver trade with Japan, in which the Portuguese acted as middlemen between the Chinese and the Japanese (Flynn \& Giraldez 1996: 56). There were also important connections to Southeast Asian ports, in particular Melaka and Manila (Ptak 2006). In the seventeenth century, a series of events took place that dramatically affected these connections: first, the Portuguese were expelled from Japan in 1639, due to the latter's concerns about Portuguese missionary activities on the islands (Subrahmanyam 2012: 179). Then, in 1640, the Portuguese Restoration War ended the dynastic union between Spain and Portugal (Disney 2009). This effectively ended trade between Macao and Manila, which were in Portuguese and Spanish hands, respectively. Finally, in 1641, the Dutch seized Melaka from the Portuguese (Subrahmanyam 2012: 183). Thus, within three years, Macao was deprived of its three most important markets. By the 167os, "the Macau-based traders [were] a pale shadow of the prosperous mercantile community of the early years of the same century", "searching constantly for outlets which the Dutch might permit them" (Subrahmanyam 2012: 222). ${ }^{5}$ As a result, links with Portuguese territories such as Timor, which had previously been of minor importance, became more

5 See Subrahmanyam (2012) for a more detailed analysis of the decline of the Estado da Índia in the seventeenth century. 
prominent. In fact, by the end of the seventeenth century, Timor, Solor, and some other islands in the region were the only remaining Portuguese possessions in the Far East apart from Macao. The links between the Portuguese-ruled Lesser Sunda Islands and Macao were administrative, commercial and economical, and religious. Following Sousa (2006), these are briefly discussed in turn.

Until 1844, Macao and Timor and Solor were separate territories under the jurisdiction of the Portuguese Estado da Índia. Even so, the government of the captaincy of Timor and Solor was heavily dependent on the authorities in Macao by 1836. For instance, the two territories were represented in the Parliament of Lisbon by a single ambassador (Sousa 2006: 17), and it is reasonable to assume that this person generally came from Macao. In 1844, the two Far Eastern territories were joined to form a new province, independent from the Estado da Índia. The seat of government for the Provincia de Macau, Solor e Timor was in Macao; a subordinate governor resided in Dili. In 1850, Timor and Solor were declared an autonomous province. This was a period of intense territorial conflict with the Dutch, and it is likely that the elevation of the islands to the status of a separate province was intended to give the governor the power to conduct the negotiations with the Dutch that were to lead to the 1859 Treaty of Lisbon (Sousa 2006:17). In 1851, Timor and Solor went back under the jurisdiction of Macao, and in 1856, the Far Eastern territories were subordinated again to the Estado da Índia. Timor again briefly became a separate colony in 1863 before being made an autonomous district within the newly formed Província de Macau e Timor in 1866. In 1897, Timor became independent from Macao, and from then on, it was directly administered by Lisbon. Table 2.1 sums up the administrative status of Portuguese Timor from the time it officially became a Portuguese colony in 1702 until its declaration of independence in 1975 (excluding the period between 1942-45, when it was occupied by Japan).

Regular trade relations between Macao and Timor existed since the late 1500 s (Pinto 2014: 151). In the seventeenth century, Macao imported sandalwood, slaves, turtle shells, honey, and beeswax from Timor, while Timor imported textiles, metal, gold, as well as rice purchased in Batavia from Macao traders (Sousa 2006: 18). As Macao's more lucrative markets were lost around 1640, the relative importance of Timor for the Portuguese trading network increased. In the late seventeenth century, the viceroy of Portuguese India granted Macao the monopoly on sandalwood trade from Timor, and the Timorese were banned from selling their main export commodity to the Dutch. During this period, two to three boats went from Macao to Timor annually, stopping at a 


$\begin{array}{ll}\mathbf{1 7 0 2 - 1 8 4 4} & \begin{array}{l}\text { Captaincy of Timor and Solor under the jurisdiction of the } \\ \text { Estado da Índia }\end{array} \\ \mathbf{1 8 4 4 - 1 8 5} & \text { Province of Macao, Solor and Timor } \\ \mathbf{1 8 5}-\mathbf{1 8 5 1} & \text { Province of Solor and Timor } \\ \mathbf{1 8 5}-\mathbf{1 8 5 6} & \text { Under the jurisdiction of Macao } \\ \mathbf{1 8 5 6 - 1 8 6 3} & \text { Under the jurisdiction of the Estado da Índia (jointly with Macao) } \\ \mathbf{1 8 6 3 - 1 8 6 6} & \text { Province of Timor } \\ \mathbf{1 8 6 6}-\mathbf{1 8 9 6} & \text { Province of Macao and Timor } \\ \mathbf{1 8 9 6 - 1 9 7 5} & \text { Variable status as province or autonomous district under the } \\ & \text { jurisdiction of Lisbon }\end{array}$

number of Dutch ports ${ }^{6}$ in the Indonesian archipelago along the way (Sousa 2006: 18). Next to the official channels of trade, there were also varying degrees of trade between Timor and Macao organized by private merchants from Macao (Pinto 2014). Even so, the Timor market was never a very lucrative one, and the volume of trade with Macao was relatively low. Towards the end of the eighteenth century, Timor's sandalwood reserves were depleted. The colony kept running deficits, and Macao supported it with yearly subsidies from 1811 onwards (Gunn 1999: 52), even in periods when there was no direct administrative link between the two territories. Records from the period when Timor and Macao were joined in the Província de Macau e Timor in 1866 show that these subsidies were unpopular with the population in Macao. In the same period, Macao military personnel were obliged to two years of service in Timor (Sousa 2006: 17).

Macao and Timor were also tightly linked by religious connections, in particular during the 180os. In the early part of the century, missionaries were sent from Macao to Timor to help promote Catholic religious education in Timor. In 1864, Timor was made part of the diocese of Macao and remained part of that diocese until 1940. Missionary efforts were renewed towards the end of the nineteenth century, when missionaries, priests, and nuns were sent from Macao to Timor (Sousa 2006: 20-21). While many of them were Portuguese, there were also some Chinese people among them. For instance, Sousa (2006: 21) reports that a group of missionaries and priests arriving from Macao in

6 E.g. Batavia, Melaka, Madura, Bali, and Larantuka. 
1877 included a Cantonese priest, whose focus was on converting the Chinese of Timor to Catholicism.

The various administrative, commercial, and religious links may furthermore have resulted in a linguistic connection between Timor and Macao: Bidau Creole Portuguese, spoken in Dili until the twentieth century, exhibits a number of striking similarities with Macao Creole Portuguese and was likely influenced by it (Baxter \& Cardoso 2017: 297).

\section{The Chinese-Timorese Community}

Throughout most of the nineteenth century, both the Portuguese and the Dutch had limited control over the Timorese hinterland. In this period, the island formed an "integrated whole" with respect to Chinese business activities (Kammen \& Chen 2019: 21). By the early twentieth century at the latest, the ethnic Chinese of West Timor and East Timor can be considered separate communities. The extent to which they have developed along separate ways historically and linguistically is a topic for further research. This section highlights, successively, the history of the Chinese community of East Timor from the colonial period, the Indonesian occupation, to the present day. More indepth accounts can be found in Kammen \& Chen (2019) and Soares (2019).

\subsection{Origins and the Colonial Period}

In the fourteenth century, Timor was the southernmost endpoint of Chinese trading voyages in Southeast Asia (Gunn 2016: 128; Kwartanada 2001: 2), and Timor is mentioned as a place rich in sandalwood in a thirteenth century Chinese source, Zhao Rugua's 趙汝适 account of countries outside China and the products they traded (Hirth \& Rockhill 1911: 208-9). According to Ptak (1987; quoted in Sousa 2006:14), trade relations between China and Timor may date back as early as the twelfth century. In any case, by the time the Portuguese arrived in the region, Chinese traders were "an accepted part of the scene in the waters round Timor" (Ormeling 1956).

During the colonial period, the most prominent Chinese settlements on Timor were in Kupang, Lifau, and Dili. Near the island's western tip, Kupang was the site of a Portuguese settlement established in 1646 (Pinto 2014: 144), but was captured by the Dutch only 7 years later (Jannisa 2019: 48). Today, it is the capital of Indonesia's Nusa Tenggara Timur province. Lifau, located in Timor-Leste's Oecussi enclave, was the seat of government of Portuguese Timor from 1702 until 1769 (Jannisa 2019:47). At that point, the colony's capital was moved to Dili. The earliest reports of a Chinese community living on Timor 
come from Lifau: in 1699, a British naval officer who passed by the island made note of a few Chinese living there, and a few years later, in 1702, the ordinance of the Portuguese judicial officers of Lifau distinguished Portuguese, Timorese, and Chinese residents for tax purposes (Pinto 2014: 158-59). In the early eighteenth century, Chinese traders also began to settle in Kupang (Hägerdal 2010: 23). By 1770, Kupang had a Chinese neighbourhood complete with a Chinese temple (Lombard-Jourdan \& Salmon 1998: 396). It is unclear when the first Chinese settled in Dili, although this city appears to have risen to prominence as a centre of Chinese activity only after it was made the capital of Portuguese Timor. Records show that in 1785 the colony's governor publicly invited Chinese traders to settle in the new capital in an effort to stimulate its economy. A few years later, he reported that seven Chinese traders had established themselves in Dili, and a capitão Cina $^{7}$ existed by the early nineteenth century (Pinto 2014: 159; cf. Kammen \& Chen 2019: 52). According to Figueiredo (2004: 228), 2o Chinese lived in Dili's Bidau neighbourhood in 1812.

Immigration from China to Portuguese Timor followed two patterns, an official and an informal one (Pinto 2014). The official channel linked East Timor to Macao. Orchestrated by the colonial authorities, it mainly concerned "the trade in sandalwood and the Macao government's occasional efforts to bring craftsmen and workers to the island" (Pinto 2014: 161). Efforts to boost the remote colony's economy by encouraging the immigration of Chinese merchants and craftsmen started in the late eighteenth century and continued throughout the nineteenth century. Portuguese Timor also served as a place of exile for convicts from Macao. It was among "the most challenging tropical locations" (Coates 2018: 49-50) in the Portuguese empire, ${ }^{8}$ and to be exiled to Timor was reserved as punishment for the most serious crimes. In 1844, a report in the Macao newspaper A Aurora Macaense criticized the long-standing practice of "dumping its most incorrigible, uncouth, and uneducated convicts" (Gunn 1999: 52; cf. Sousa 2006: 21) in Timor. This form of punishment was practiced at least from the first half of the nineteenth century until after the Second World War (Kammen \& Chen 2019: 22, 110).

The informal channel involved private individuals, departing from a variety of ports (including Macao, Swatow, and Hong Kong) and travelling to Portuguese Timor by different routes (Kammen \& Chen 2019: 54-56). This

7 This title referred to an official tasked with overseeing the community and liaising with the colonial government. This system was copied from the Netherlands Indies (Kammen \& Chen 2019: 52) and can be traced back to pre-colonial times (Ooi 2004).

8 Recall also that Kammen \& Chen (2019) described Timor as "the most backward of European colonies" (cf. section 2.2). 
channel became significant around the middle of the nineteenth century, when a series of upheavals in southern China (the Opium Wars of the 1840s, severe floods between 1846-48, the Taiping Rebellion and the Punti-Hakka Clan Wars in the 185 os and 186os) caused emigration from the region to soar. While Portuguese Timor was by no means a prominent destination, a portion of the migrants found their way there (Kammen \& Chen 2019: 35-36), and the informal channel soon overtook the official one, contributing a much larger number of Chinese immigrants.

Throughout the eighteenth and nineteenth centuries, the volume of migrants brought to Portuguese Timor via both channels remained on a low level. Sousa (2006: 18) reports that by around 1800 , some 300 Chinese families, mainly from Macao, were living scattered on the island; in other words, this number included both the Portuguese and the Dutch parts of Timor. The Chinese community of Portuguese Timor started to increase dramatically in the early twentieth century (Kwartanada 2001:4; Kammen \& Chen 2019:56-57). This surge was caused by two events, namely the overthrow of the monarchy in Portugal in 1910, and the end of the Qing Dynasty in China in 1911. In China, the turmoil following the overthrow of the Qing resulted in a wave of emigration to Southeast Asia. The establishment of the Republic in Portugal resulted in administrative and economic reforms of the empire which facilitated Chinese immigration (Kammen \& Chen 2019: 81-82). The Chinese population of Timor continued to increase in the post-wwil period, both through high birth rates as well as immigration (Kammen \& Chen 2019: 110, 114).

Fig. 2.3 illustrates the growth of the Chinese community of Portuguese Timor from the late nineteenth century up to 1970; the numbers on which this graph is based are taken from Kammen \& Chen (2019: 29, 38, 70). The figures for 1907,1927,1950 and 1970 come from colonial censuses, while the nineteenth century figures are estimates. Despite the considerable growth in the twentieth century, the community remained small both in absolute numbers as well as relative to the colony's total population: in 1927, ethnic Chinese residents made up $0.37 \%$ of Portuguese Timor's population; in 1950, $0.71 \%$; and in 1970, approximately 1.0\%. ${ }^{9}$ It must be noted, however, that the figures for the Chinese population of the colony may be somewhat too low, as some Chinese may have tried to "dodge the census taker so as to avoid payment of the annual fee for foreigners" (Kammen \& Chen 2019: 71).

9 The total population of Portuguese Timor was 451,604 in 1927 (Telkamp 1975: 6-7 quoted in Kwartanada 2001: 5), 442,378 in 1950, and 609,477 in 1970 (Telkamp 1979: 75). Again, the figures come from colonial censuses. 


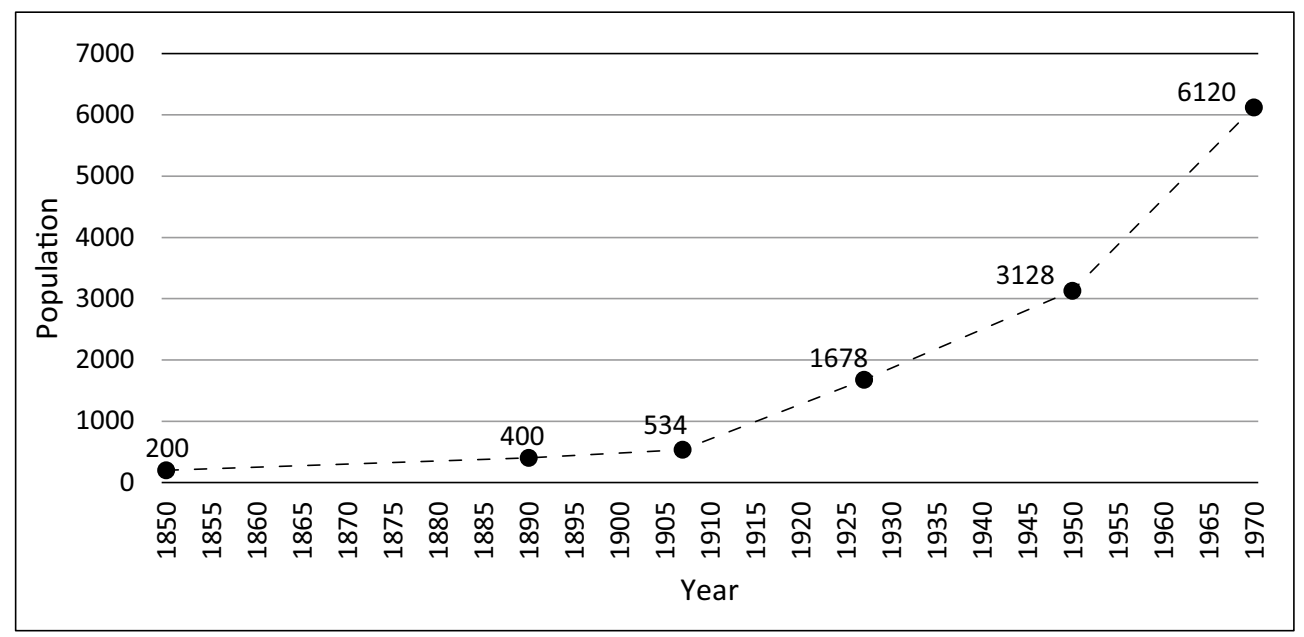

FIGURE 2.3 The East Timorese Chinese community in numbers, 1850-1970 OWN WORK

Despite their small number, the ethnic Chinese dominated the economy of Portuguese Timor. Several early sources stress that the Chinese-Timorese "were the most useful part of the population" (Gunn 1999: 60), or "the only part of the population which carries on trade" (Kwartanada 20o1: 3; cf. also Sousa 2006: 19; Pinto 2014: 157). By the mid-18oos, the Chinese in Dili controlled the small and medium retail business as well as a significant part of the export business (Pinto 2014: 163), and in the early 196os, all but three or four of some 400 plus wholesale and retail businesses in the colony were owned by ethnic Chinese businessmen (Dunn 1983: 9). The Chinese-Timorese were also "the main brokers of the grain and coffee markets" (Kwartanada 2001: 7). Beyond trade and commerce, Chinese craftsmen such as stonemasons and carpenters were highly sought after by colonial officials, who bemoaned the shortage of skilled labour among the indigenous East Timorese (Sousa 20o6: 19). It appears that many of the Chinese craftsmen were contract labourers, a large proportion of whom presumably returned to China after the end of their contracts (Kammen \& Chen 2019: 35, 54).

Throughout the colonial period, ethnic Chinese businessmen served as intermediaries between the indigenous population and the Portuguese as well as other parts of the outside world. Kwartanada (2001) characterizes them as a middleman minority, i.e., a minority group "serving an intermediary position between the majority group and other segregated minority groups" (Douglas \& Sáenz 2007: 147). Middleman minorities are usually sojourners who migrate 
for economic reasons and "tend to concentrate in certain occupations, notably trade and commerce" (Bonacich 1973: 583). Many Chinese merchants sought to strengthen good business relationships with Timorese chiefs by marrying women from their families (Nicol 2002: 31). The Chinese were also closely associated with the colonial powers (see Pinto 2014:159; Nicol 2002: 31), who relied on them not only for their personal needs, but also for the collection of head taxes from the indigenous population in the rural areas of East Timor. As such, they were "a condition for [the state's] very existence and ability to function" (Kammen \& Chen 2019: 98).

Despite their reliance on them, the Portuguese colonizers' attitude towards the Chinese-Timorese minority was marked by distrust. The Portuguese aimed to restrict and control Chinese immigration and trade, and Chinese-Timorese merchants were often at risk of falling "victim to capricious colonial officials and military personnel" (Kammen \& Chen 2019: 42). Discriminatory practices continued into the twentieth century and included not being allowed to loiter in the streets after 8:00 pm; needing a permission for slaughtering animals and a license to employ workers; and restrictions on travel and visa requirements (Kammen \& Chen 2019: 96, 123). In response, the Chinese community developed a high degree of solidarity and a strong sense of identity (Kammen \& Chen 2019: 82, 98; Wise 2006: 154). A system of social institutions such as business and self-help associations "entirely out of proportion to [the community's] size" offered "protection from the most repressive expressions of state authority" (Kammen \& Chen 2019: 98). There was also a well-established school system, with at least one Chinese school in every district by 1933 (Kammen \& Chen 2019: 88). Up to 1975, Chinese-Timorese children generally attended Portuguese schools as well as Chinese schools where they were available. A Chinese-Timorese woman quoted in England (1999) reports that "[b]efore 1975, I went [to a Chinese school] in the mornings and to the Portuguese school in the afternoons". The Chinese schools in Portuguese Timor were supported with textbooks and teachers from Taiwan (Chew \& Huang 2014: 313) and China (Wise 2006:147), and instruction took place either in Hakka or in Mandarin (cf. Chew \& Huang 2015: 313).

Among the Chinese cultural institutions in Dili were also a temple and a cemetery. A first temple was destroyed around 1915. A new one, the Guandi temple 關帝廟, was built in 1928 and still exists today (Timor Tourism 2015). A part of the Chinese-Timorese community practiced Chinese folk religion and Buddhism, while, as mentioned previously, substantial numbers also adopted Catholicism. In many instances, the belief systems existed side-byside. For instance, some families attended both the Chinese temple as well as Catholic church services (Raynor 2019; cf. Chew \& Huang 2014: 317). In 
the Chinese cemetery in Dili, both graves with Christian symbols as well as those invoking deities from Chinese folk religion can be found. Berlie (2015: 42) notes in particular the importance of Tushen 土神, the genius loci of Chinese popular religion, in the cemetery, which he takes as evidence of how the Chinese-Timorese have taken root in Timor (cf. Tan 2018). In general, a Chinese-Timorese culture developed which was characterized by "mixed cultural forms influenced by a long period of Portuguese colonial rule on East Timor" (Chew \& Huang 2014: 301-2). Notably, however, "forms of social organization characteristic of overseas Chinese elsewhere in Southeast Asia were far less important in Timor" (Kammen \& Chen 2019: 85); for instance, surname associations were practically absent.

An early nineteenth-century source notes that the Chinese-Timorese community of Dili was of mixed origin (Pinto 2014: 159). According to Kammen \& Chen (2019: 37-8, 54-5, 59), three main linguistic groups of Chinese immigrants can be identified: Hokkien, Hakka, and Cantonese. The linguistic background of these groups tends to correlate with some social characteristics. Hokkien speakers ("Baba”; see Kammen \& Chen 2019: 37) made up the majority of the earliest immigrants, who arrived in Timor in the eighteenth and early nineteenth century, well before the colonial spheres of dominance were fully consolidated. They were centred in Kupang, in today's West Timor. From there, they spread along to the north coast of the island to Dili and other towns in Portuguese Timor. Most were merchants and presumably made their way to Timor via the informal channel of immigration.

Cantonese speakers from the Pearl River Delta arrived in relatively small numbers either as skilled labourers or as convicts. As noted above, efforts to bring merchants and craftsmen to Portuguese Timor started in the late eighteenth century. Convicts were sent to Portuguese Timor from at least the first half of the nineteenth century up until the 195os. In the twentieth century, they made up the majority of Cantonese speakers arriving in the colony (Kammen \& Chen 2019: 66-67). Skilled labourers were mostly on short-term contracts and left Timor when their contracts ended. Although they were at the bottom of the social ladder within the Chinese-Timorese community, convicts often stayed on, finding jobs as carpenters or construction workers (Kammen \& Chen 2019: 134).

Hakka speakers started arriving in the second half of the nineteenth century, many fleeing from upheavals in China. By the twentieth century, the majority of Chinese immigrants to Portuguese Timor were Hakka speakers. There were two distinct Hakka groups, those from Xiangshan County 香山縣 (near Macao), and those from Jiayingzhou 嘉應州 (Meixian) in north-eastern Guangdong, who brought with them distinct Hakka dialects. The two groups 
TABLE 2.2 Estimated percentage of Chinese in Portuguese Timor by speech-group

\begin{tabular}{lrrrr}
\hline \multirow{2}{*}{ Year } & \multirow{2}{*}{ Hokkien } & \multicolumn{2}{c}{ Hakka } & \multirow{2}{*}{ Cantonese } \\
& & Xiangshan & Meixian & \\
\hline 1900 & $20-25 \%$ & $25 \%$ & $25-30 \%$ & $25 \%$ \\
1915 & $15 \%$ & $20 \%$ & $40 \%$ & $25 \%$ \\
1940 & $10 \%$ & $15 \%$ & $55 \%$ & $20 \%$ \\
1975 & - & $10 \%$ & $75-80 \%$ & $10-15 \%$ \\
\hline
\end{tabular}

FROM KAMMEN \& CHEN (2019: 79)

were present in Timor in roughly equal numbers at the turn of the twentieth century, but by the end of the colonial period, Meixian Hakka made up the vast majority of the Chinese-Timorese community overall. Table 2.2 illustrates how the make-up of the community changed over time.

Up to the early twentieth century, the Chinese-Timorese community was mostly male. Many of the early Hokkien-speaking immigrants thus married Timorese women. Marriages with women from local ruling families were also an important means of establishing business relations (Kammen \& Chen 2019: 43). Situated at the bottom of the social ladder, Cantonese-speaking convicts were likely to remain single or marry Timorese women (Kammen \& Chen 2019: $134,145)$. Only in the twentieth century, a sufficient number of Chinese women arrived to allow the community to consolidate (Kammen \& Chen 2019: 79). Most were Hakka and tended to marry other Hakka speakers. Mixed marriages were also more likely to happen in rural settings: Chinese men who established themselves in rural areas were more likely to marry East Timorese women and became more integrated in East Timorese society and culture (Wise 2006: 150). It was mostly Hakka speakers who ventured beyond the urban centres, while the majority of Hokkien and Cantonese speakers remained in the cities (Kammen \& Chen 2019: 73-74).

\subsection{The End of the Colonial Period and the Indonesian Occupation}

By the end of the colonial period, Dili had become the centre of Chinese cultural and institutional life in East Timor. However, several major district seats also had significant numbers of Chinese residents (Kammen \& Chen 2019: 82, 74), and there were few rural areas which "did not at least have one Chinese shopkeeper" (Hajek 2000: 218). The inhabitants of the remote subdistrict seat of Iliomar on the south-eastern coast of Timor-Leste, for instance, still 
remember the Chinese shopkeeper known as Sina Fernando ${ }^{10}$ who used to live there; his shop is now in ruins. As shown in the introduction, the Chinese were very much an accepted part of East Timorese life and had found their way into ritually significant expressions of indigenous East Timorese culture. There are no reports of open animosity between the East Timorese and the Chinese-Timorese, and it appears that "Chinese cultural issues and identity posed no problems to the other groups settled in and around Timor" (Pinto 2014: 158). Nonetheless, the relations between the two groups were not without problems. Some East Timorese resented the self-imposed social isolation of the Chinese-Timorese community (Nicol 2002: 58), and jealousy over their economic success can also be assumed to have been widespread (cf. Kammen \& Chen 2019: 157). Chinese-Timorese were furthermore accused of a "lack of commitment" to East Timor. For instance, many Chinese-Timorese opted for ROC citizenship rather than Portuguese citizenship. According to stories circulating among East Timorese expats in Australia, it was only when they hoped to gain the status of East Timorese refugees that the Chinese-Timorese referred to themselves as East Timorese and tried to obtain Portuguese passports (Wise 2006: 157; Kammen \& Chen 2019: 134-35). ${ }^{11}$

During the colonial period, the Chinese-Timorese community had steadily increased in size. The events surrounding the Indonesian occupation of East Timor resulted in a dramatic reduction of the community. Assuming a constant growth rate and taking into account the fact that the actual population was likely somewhat larger than what is reported in official figures mentioned previously, Kammen \& Chen (2019: 72) estimate that some 7,500-8, ooo ethnic Chinese people lived in Portuguese Timor by 1975. It must be noted, however, that other sources give - sometimes drastically - different estimates. For instance, Dunn (1983: 9) quotes a lower number of 6,170, although he concedes that this figure omits the so-called Chinese-Timorese mestizos "who considered themselves Chinese in cultural terms". A number almost twice that given in Kammen \& Chen (2019), 14,ooo, appears in Telkamp (1979: 76). An even higher estimate is given by Berlie (2015: 40), according to whom the community numbered up to 25,00o people, and Miao et al. (2015) quote a number as high as 30,000 . The total population of Portuguese Timor at the time is estimated to have been about 700,ooo (Kwartanada 2001: 5; Telkamp 1979: 75).

\footnotetext{
$10 \quad$ Sina refers to both China as well as Chinese people.

11 Hostility directed at middleman minorities from the host society is common (Bonacich 1973: 589-93). In particular, accusations of disloyalty to the host country, or dual loyalty, are a recurrent theme (Bonacich 1973: 591).
} 
At 8,ooo, the Chinese-Timorese would thus have accounted for $1.5 \%$ of the colony's population. ${ }^{12}$ Although this is a clear increase from 1970, when they made up $1 \%$ as mentioned above, the Chinese-Timorese still remained a tiny minority in East Timor.

The decline of the Chinese-Timorese community set in even before the Indonesian invasion, namely in the time leading up to Portuguese Timor's declaration of independence in 1975. In this period, Fretilin, as the strongest of the newly formed political parties, called for "an end to foreign exploitation and a people's economy based on self-sufficiency and cooperatives" (Kammen \& Chen 2019:152), and some anti-Chinese sentiments were expressed (Nicol 2002: 60 ). Many Chinese-Timorese were thus worried about their prospects in an independent Timor-Leste. In addition, memories were still fresh of Indonesia's Communist Purges in 1965-66, during which many Chinese-Indonesians had lost their lives. As a result, as many as 2,0oo Chinese-Timorese fled East Timor in this period (Kammen \& Chen 2019: 155; Nicol 2002: 6o).

During the 1975 invasion and the ensuing 24-year occupation mentioned in the previous section, Indonesian forces reportedly specifically targeted Chinese-Timorese (Kiernan 2003: 202). According to Dunn (1983: 285-86), some 700 Chinese-Timorese were killed in Dili in the first days of the invasion, and the Chinese communities of several other towns were practically wiped out. However, based on eyewitness accounts, Kammen \& Chen (2019: 16o, fn. 65) conclude that 700 Chinese-Timorese did not lose their lives in Dili in the invasion. It is true that the Chinese-Timorese inhabitants of the Lecidere, Colmera and Taibesi districts of Dili found themselves "near the front lines and drew the immediate attention of Indonesian military personnel", but in most cases, the Indonesian soldiers left "Chinese men, women, and children frightened but unhurt" (Kammen \& Chen 2019: 159). The vast majority of victims in Dili were in fact indigenous East Timorese, not Chinese-Timorese.

Even if the death toll of the invasion was lower among the Chinese-Timorese than previously reported, life under Indonesian rule became exceedingly difficult. They were viewed with distrust by the Indonesian occupiers, who associated "the Chinese with communism, and communism with Fretilin" (Kammen \& Chen 2019:162). Due to a lack of business opportunities, many were forced to live off of their savings (Kammen \& Chen 2019: 162). The Indonesian government "prohibited any activities that were culturally Chinese" (Kammen \& Chen 2019: 16o). In addition, all Chinese schools were closed. However, a consultant reports that clandestine Mandarin classes continued for a while and were attended by a significant number of Chinese-Timorese children (Lay

12 Or up to 4.3\%, assuming Miao et al.'s (2015) estimate of 30,000. 
Li Sum p.c., 14 April 2020). Religious activities were still permitted, and Dili's Guandi temple emerged from the invasion unscathed (Fong Kui Kong p.c., 16 August 2017; Miao et al. 2015).

In response to the difficult conditions in East Timor, those who had the means to do so fled the country. By 1980, an Indonesian state census showed that no more than 2,00o ethnic Chinese remained in East Timor. They were presumably stateless, that is, they had neither Roc nor Portuguese passports or lacked the financial resources to leave, or were "bound to Timor by marriage, political commitments, or fateful accidents" (Kammen \& Chen 2019: 163).

A second wave of emigration took place in 1999, when, in retaliation for the vote in favour of independence, pro-Indonesian militia went on a rampage through the country. It is reported that, again, the remaining Chinese-Timorese and their residences were specifically targeted. During the 24-year Indonesian occupation, 90\% of Chinese-Timorese are estimated to have left East Timor, with the majority fleeing to Australia and Macao (Wise 2006: 147; Sousa 2006: 17); others made their way to Portugal or Singapore, and some also went to West Timor or other parts of Indonesia (Kammen \& Chen 2019: 163 Lay Li Sum p.c., 21 August 2017; Fong Kui Kong p.c., 16 August 2017).

\subsection{Independent Timor-Leste}

The exact number of Chinese-Timorese living in Timor-Leste today is difficult to determine, as the population censuses conducted by the country's General Directorate of Statistics do not provide information on ethnicity or ancestry. ${ }^{13}$ According to Berlie (2015: 41), 2,400 Chinese-Timorese were registered with the Hakka association of Timor-Leste in the 2010s. A newer estimate is found in Soares (2019: 317), who offers a number of some 4,0oo for 2014. Soares (2019: 315) furthermore estimates that between 4,500 and 5,00o new Chinese migrants lived in Timor-Leste at the time of writing. It is unclear whether this number refers to post-independence newcomers from China only, or also Chinese-Indonesians who migrated to East Timor in significant numbers during the Indonesian occupation (Soares 2019: 317). It does show, however, that the established Chinese-Timorese community may well be outnumbered by more recent migrants of Chinese descent.

The rather substantial increase in community size from 2,400 to 4,000 between ca. 2010 and 2014 is most likely owed to the post-independence return of Chinese-Timorese people who had left the country during the Indonesian occupation. Whether this rising trend has continued since 2014 is questionable.

13 However, the censuses contain information on mother tongue, which is discussed in section 4 . 


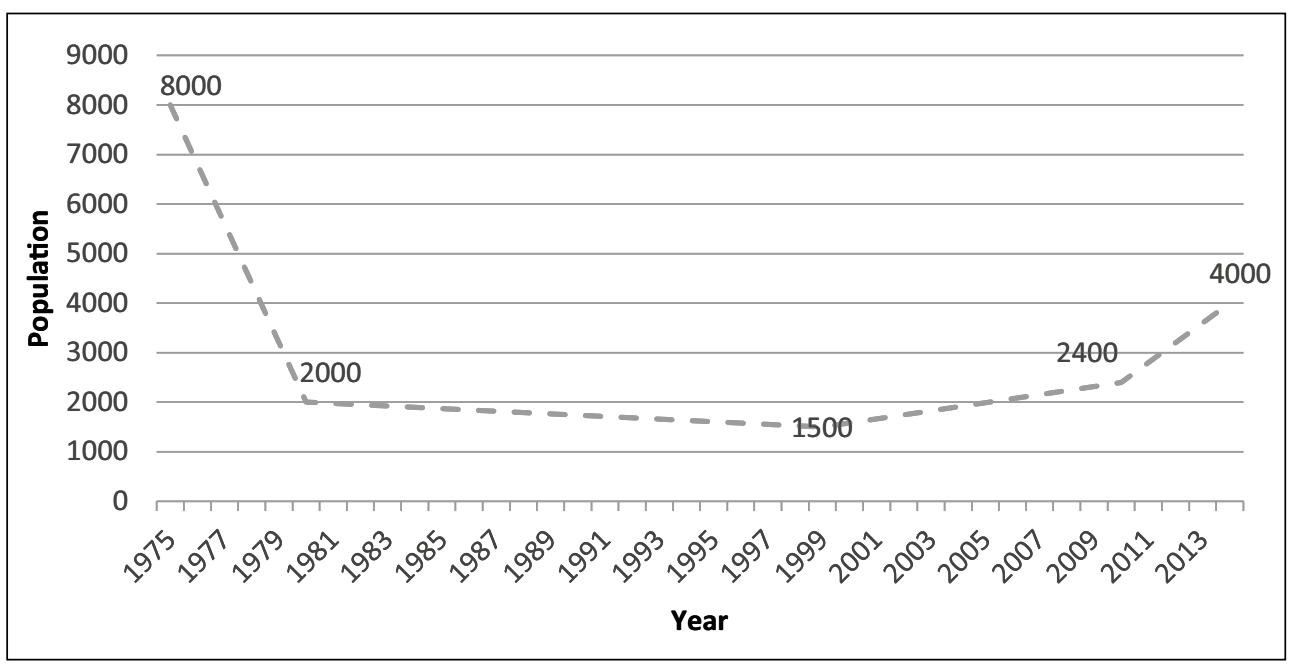

FIGURE 2.4 The East Timorese Chinese community in numbers, 1975-2014 OWN WORK

It is likely that the majority of Chinese-Timorese who were willing to return to Timor-Leste had already done so by 2014 .

Fig. 2.4 illustrates the population development since 1975. As discussed above, the Indonesian invasion had a dramatic impact on the ChineseTimorese community. ${ }^{14}$ In absolute terms, the post-independence growth brought it back to approximately half of the pre-invasion level. In relative terms, however, it is at a level close to that of 1927 as we saw above: according to Timor-Leste's 2015 census (General Directorate of Statistics 2015), the country's total population was $1,183,643$. The 4,000 or so Chinese-Timorese thus accounted for a mere $0.34 \%$.

The Chinese-Timorese community today is small and close-knit: as England (1999) reports, "everyone is a little bit family". The most prominent surnames are Lay, Lai and Lee (黎, 賴, 李), ${ }^{15}$ Lim 林, Vong 黃, and Chung 鍾. To the present day, the Chinese-Timorese are dominant in the retail industry. Many are involved in construction work as government contractors or operate petrol stations and hotels. They tend to be among the wealthy in Timor-Leste, and

14 The 1975 and 1980 figures are from Kammen \& Chen (2019). I have been unable to find a figure for the second wave of emigration which took place in 1999 (see section 2). The number of 1,500 in Fig. 2.4 is my own rough guess.

15 Before the standardization of romanization systems, the same name could be romanized in different ways and at the same time, a given romanization could conflate different names (Kammen \& Chen 2019: xii). 
it is very common for families to send their children abroad to study. There they will generally stay with relatives; indeed, everyone seems to have family abroad, especially in Australia. Most Chinese-Timorese people I spoke to had themselves spent at least some time abroad as refugees. A significant proportion of young people has been educated abroad. Many of them returned to Timor-Leste to help their parents in their businesses or to take care of them.

In contrast to Indonesia, where attitudes toward the Chinese are often marked by resentment and racism (cf. England 1999), the relations between the Chinese-Timorese and indigenous East Timorese are mostly amicable (Pinto 2014: 158; Berlie 2015: 40-43; Mulyanto 2019). In the face of the increasing numbers of new Chinese migrants, the consensus among the East Timorese appears to be that " $[\mathrm{m}]$ ost Chinese are all right, [...] but local Chinese are best" (England 1999). A Chinese-Timorese man quoted in England (2001) confirms that "it's easy to do business here because I am a local Chinese". The Guandi temple in Dili is "indicative of how well the ethnic Chinese and their culture have been accepted by the society" (Mulyanto 2019). The temple is visited not only by ethnic Chinese, but also by indigenous East Timorese who seek blessings or have their fortunes read (cf. Mulyanto 2019; Miao et al. 2015). During my visit in 2017, the head of the temple, a Chinese-Timorese man, was supported by two indigenous East Timorese assistants who mainly performed janitorial duties, but also helped guide and instruct visitors to the temple when it was particularly busy. Since independence, Timor-Leste has had two ChineseTimorese ministers: Pedro Lay (sometimes Pedro Lay da Silva) was Minister of Infrastructure between 2007 and 2012 and Minister for Transport and Telecommunication between 2012 and 2015. His brother, Francisco Kalbuadi Lay, was Minister of Tourism (later Minister of Tourism, Arts and Culture) between 2012 and 2017.

Nevertheless, there are reports of animosity towards the Chinese-Timorese from the indigenous East Timorese majority. Discrimination may take many forms, from "subtle over-charging for vegetables in the market [...] and insults hurled from bored youths street-side to more sinister acts of violence" (Raynor 2019). The appearance of two recent news articles addressing this problem (Raynor 2019; Mulyanto 2019) seems to suggest that it is increasingly being acknowledged. In a Facebook comment to Mulyanto (2019), Timor-Leste's former president and co-recipient of the 1996 Nobel Peace Prize, José RamosHorta, praises the article and states that the Chinese-Timorese "are very Timorese in every sense". Echoing the Portuguese colonial governors of past centuries, he also welcomes new Chinese immigrants: "In Timor-Leste, they are very welcome, we do not fear them, they are energising [sic!] our country's economic life". According to Wise (2006: 158), members of the East Timorese 
diaspora in Australia generally express the sentiment that it is fine for the Chinese-Timorese to practice their own culture, but their primary allegiance should clearly be to Timor-Leste.

In the early 200os, Timorese politicians, including Ramos-Horta and former resistance leader Xanana Gusmão, visited the large Chinese-Timorese expat community in Australia in order to encourage them to return to Timor-Leste and help build the young country's economy (Wise 2006: 158). While some have returned, a large number remains overseas. Wise (2006: 147) estimates that out of the $90 \%$ of Chinese-Timorese who have left Timor-Leste during the occupation, more than two-thirds went to Australia; and according to Chew \& Huang (2014: 306), the majority of Chinese-Timorese lived in this country at the time of writing.

According to Australia's Department of Immigration and Citizenship (2016), 5,706 Timor-Leste-born immigrants (48.6\%) in the country report having Chinese ancestry, and $44.7 \%$ speak Hakka at home. The biggest Chinese-Timorese communities are found in Melbourne, Sydney and Darwin; smaller communities are in Brisbane and Perth (Wise 2006: 147). Outside Timor-Leste, there is a strong sense of identification as specifically ChineseTimorese: Wise (2006: 154) reports that the Chinese-Timorese in Australia go to "extraordinary lengths" to get together, and that they prefer to "mix with other Chinese-Timorese rather than Chinese communities at large or other Timorese communities". This, she argues, is evidence of the "sense of difference from other Chinese and East Timorese and identification with East Timorese Chineseness" (cf. Hajek \& Goglia 2019). Likewise, Chew \& Huang (2014) note how active the Chinese-Timorese are on Facebook, having established many Facebook groups and using this platform to organize get-togethers and cultural events.

Berlie $(2015: 38)$ describes the Chinese-Timorese community as being characterized by a "Hakka-dominant homogeneity". This description is apt synchronically, but, as we have seen above, historically, speakers of two distinct Hakka dialects as well as Hokkien and Cantonese were present in East Timor. Hakka speakers started to arrive in large numbers in the second half of the nineteenth century, and by the early twentieth century, they made up

16 Many thanks to my Timor Hakka consultants, and especially Mr. Lay Sum Li, for patiently answering my many questions. 
the majority of the Chinese-Timorese community. In 1975, Kammen \& Chen (2019: 79) estimate that between $85^{-90 \%}$ of the community were Hakka speakers. Today, few Cantonese speakers, most of whom are elderly, remain in Timor-Leste. Their descendants have mostly switched to Hakka (Lay Sum Li p.c., 16 March 2020). My consultants are not aware of any Hokkien speakers among them (cf. Table 2.2).

The Hakka variety of East Timor is referred to here as Timor Hakka. Not many people in Timor-Leste speak Timor Hakka today: according to the 2015 population census (General Directorate of Statistics 2015) the number of mother tongue speakers of Chinese in the country is 827, of whom 599 live in the capital Dili. The next highest concentrations, with 51 and 42 speakers respectively, are reported for the Liquiça and Manatuto districts, which abut on the Dili district to the east and the west along the north coast of Timor. It is not clear, however, that the term "Chinese" used in the census publications refers to Timor Hakka. The number of Chinese nationals living in TimorLeste is given in the census as 850 . The near-coincidence of these figures suggests that the number of 827 Chinese mother tongue speakers refers to recent immigrants from China. ${ }^{17}$ If this interpretation is correct, Timor Hakka is not included in the census at all. In that case, its speakers might be subsumed in the "Other" category, which numbers 617 speakers. It is thus hard to make an accurate statement on the number of Timor Hakka speakers in Timor-Leste today.

As noted in the previous section, Soares (2019: 317) estimates that some 4,000 Chinese-Timorese lived in Timor-Leste in 2014. Assuming the 827 mother tongue speakers of Chinese reported in the 2015 census are speakers of Timor Hakka, the discrepancy between these numbers seems to suggest that as few as one-fifth of people who identify as Hakka or Chinese-Timorese actually speak Hakka as a mother tongue. Indeed, it is not uncommon to meet people who have Hakka surnames and identify as Hakka, but do not speak the language. It is my impression that these people are predominantly in their thirties or younger. Likewise, in Australia, language competence in Timor Hakka

17 The same unclarity is found in volume 2 of the publications accompanying the 2010 census (General Directorate of Statistics 2010), which reports a number of 722 mother tongue speakers of Chinese living in Timor-Leste on p. 204. P. 196 of the same report gives the number of Chinese nationals living in the country as 1,139. On p. 11, the report states that "[f]or non-Timorese people, the person's main language was recorded", which would suggest that the 722 Chinese speakers include also post-independence newcomers. In this case, however, the discrepancy between the number of Chinese nationals, who surely are native speakers of a Sinitic language, and that of mother tongue speakers of Chinese would require explanation. 
is decreasing in the second and following generations, following the typical pattern of three-generation shift to English (Chew \& Huang 2014: 314-16). As discussed in section 2.2, Hakka does not have official recognition in Timor-Leste. It is primarily a home language and is limited to the oral domain. No Timor Hakka literature is known, and whether there are distinct stylistic repertoires is unclear. It is not generally learned by community outsiders (although indigenous East Timorese employees in Hakka-owned family businesses may pick it up and speak it well if they work with the family in close proximity; Lay Sum Li p.c., 21 August 2017). ${ }^{18}$ All speakers are at least bilingual with Tetun (Timor-Leste's Austronesian lingua franca), and depending on their biography, may know a variety of additional languages such as Portuguese, Indonesian, Mandarin, English, or other Timorese languages. In sum, with a low number of speakers below the age of 30 , no official recognition, and a limited domain of use, Timor Hakka is an endangered language variety.

To date, no information on the linguistic characteristics of Timor Hakka is available. Anecdotal evidence suggests that a distinct localized Timorese variety of Hakka has developed in East Timor: according to John Hajek (p.c., 20 February 2015), when Australian authorities sent Hakka speakers from Malaysia to act as interpreters for Chinese-Timorese immigrants, they had trouble communicating; and one of Wise's (2006: 149) interviewees says: "Our Hakka has evolved and is different to mainland Chinese Hakka. Sometimes it's a problem, because it means we tend to mix more with only Chinese-Timorese", likewise suggesting that Timor Hakka speakers may not be able to communicate easily with speakers of other Hakka varieties. Speakers of Timor Hakka in Dili and more recent Chinese-Indonesian immigrants from Kalimantan, on the other hand, acknowledge lexical differences between their respective Hakka varieties, but can communicate without major problems. In any case, Hakka is an important part of the Chinese-Timorese identity (Wise 2006: 149).

A number of factors may have contributed to the emergence of Timor Hakka as a distinct variety differing from those spoken in e.g. Malaysia or Indonesia: a) the particular Hakka dialect brought to Timor from China by a significant portion of the original immigrants; b) the development of a koine variety in Timor by immigrants speaking different dialects; and c) contact with local

18 Some degree of integration of local people into Hakka society appears to have been fairly common in Hakka settlements in rural Indonesia: according to Heidhues (1996: 177), local wives and their children commonly adopted the Hakka language and Chinese dress. Thanks to Tom Hoogervorst for making this source available to me. 
languages as well as the colonial language. ${ }^{19}$ Kammen \& Chen (2019: 79) show that the Chinese-Timorese community is predominantly made up of Meixian Hakka speakers (cf. Chew \& Huang 2014: 306). Table 2.3 provides a preliminary lexical comparison of Timor Hakka with the Meixian dialect (data from Hashimoto 2010) and the variety spoken around Hong Kong (Bao'an 寶安; data from Chappell \& Lamarre 2005) ${ }^{20}$ Direct comparison is complicated somewhat due to the use of different romanization systems in these sources: Chappell \& Lamarre's (2005) description of Hong Kong Hakka, an annotated edition of late nineteenth- and early twentieth-century materials from the Basel Mission to China, follows the original materials in using the Lepsius script. For Meixian Hakka, Hashimoto (2010), originally published in 1973, uses an IPA transcription expanded by some non-standard symbols from the sinological tradition. ${ }^{21}$ Timor Hakka forms come from my own data and are in a broad phonetic transcription; a full phonological analysis remains to be done. In Table 2.3, I have attempted to convert the data into a uniform, broad phonetic romanization, which is given in the first line of every cell. The data from Meixian Hakka and Hong Kong Hakka include a second line, which reproduces the romanization as found in the original source. ${ }^{22}$ Tones are omitted, as the tonology of Timor Hakka has not yet been analysed.

Table 2.3 shows that overall, Timor Hakka seems to align more with Meixian Hakka than with Hong Kong Hakka. There are, however, some cases where Timor Hakka forms are more similar to those recorded for Hakka as spoken in the Hong Kong region; a case in point is Timor Hakka swi 'water'. There is also a non-negligible number of cases where Timor Hakka forms correspond fully to neither dialect, displaying either other dialectal forms or innovative forms.

19 Cf. Skinner (1967: 104-5), according to whom the Hakka variety spoken in north-eastern Bangka (Indonesia), is "almost creolized ... with heavy borrowings from Bangkanese Malay". Thanks to Caroline Chia for bringing this source to my attention.

20 I focus in this section on the lexicon, as I have as yet done little analysis of Timor Hakka. Language change may of course affect all linguistic levels, from (segmental as well as suprasegmental) phonology to morphology and syntax.

21 An additional complexity of this source is that different conventions are used on different analytical levels: a narrow phonological transcription is used in the syllabary in the phonetics section, a somewhat broader transcription in the remainder of the phonetics section, and a romanization based on a phonological analysis in the remainder of the book. For instance, $[\mathrm{\eta}]$ and $[\mathrm{n}]$ are analysed as allophones. Thus, outside the phonology section, both are represented by $\langle\mathrm{y}\rangle$; and [ $]$, which is an allophone of both $/ \mathrm{s} /$ and $/ \mathrm{h} /$, is represented as either $\langle\mathrm{s}\rangle$ or $\langle\mathrm{h}\rangle$ (Hashimoto 2010: 101-2).

All errors in the conversion are my own. 
TABLE 2.3 A lexical comparison of Meixian Hakka, Hong Kong Hakka, and Timor Hakka

\begin{tabular}{|c|c|c|c|}
\hline English & Meixian Hakka & Hong Kong Hakka & Timor Hakka \\
\hline \multirow[t]{2}{*}{ (durative marker) } & [ten] & [kin] & [tey] \\
\hline & (den) & (kin) & \\
\hline \multirow[t]{2}{*}{ (genitive marker) } & {$[\mathrm{e}]$} & [kaj] & {$[\mathrm{ke}] \sim[\mathrm{ge}] \sim[\mathrm{e}]$} \\
\hline & $(/ \mathrm{e} /)^{\mathrm{a}}$ & (kai) & \\
\hline \multirow[t]{2}{*}{$1 \mathrm{PL}(\mathrm{EXC})$} & $-\mathbf{b}$ & [ya-teu] & [yai-ten] \\
\hline & & (nga teu) & \\
\hline \multirow[t]{2}{*}{$1 \mathrm{PL}(\mathrm{INC})$} & [yaj-ten-nin] & [naj-teu] & [tci-ga] \\
\hline & (/nai-den-nin/) & (ngai teu) & \\
\hline \multirow[t]{2}{*}{ banana } & [kiuy-tsiau] & [ya-tsjaw] & [tjuy-t6eu] \\
\hline & ([kjion-tsiau $])$ & (nga tsyau) & \\
\hline \multirow[t]{2}{*}{ blood } & [çjat $]$ & [çjet] & [sjat] \\
\hline & (/hiat/, [jiæt]) & (hyet) & \\
\hline \multirow[t]{2}{*}{$\operatorname{dog}$} & [kew-e] & {$[\mathrm{kew}]$} & {$[\mathrm{kew}-\mathrm{li}] \sim[\mathrm{kjew}-\mathrm{li}]$} \\
\hline & $([g \varepsilon u v \varepsilon])^{c}$ & (keu) & \\
\hline \multirow[t]{2}{*}{ five } & {$[\mathrm{y}]$} & {$[\mathrm{y}]$} & {$[\mathrm{m}]$} \\
\hline & $(/ \mathrm{y} /)$ & (ng) & \\
\hline \multirow[t]{2}{*}{ sky } & {$\left[\mathrm{t}^{\mathrm{h}}\right.$ jen-ji $]$} & {$\left[\mathrm{t}^{\mathrm{h}} \mathrm{en}\right]$} & {$[$ tjen] } \\
\hline & $(/$ tien-ni/) & (then) & \\
\hline \multirow[t]{2}{*}{ ten } & {$[\mathrm{srp}]$} & {$\left[\int \mathrm{ip}\right]$} & [sup] \\
\hline & $([\mathrm{sip}])$ & (šip) & \\
\hline \multirow[t]{2}{*}{ this } & [li] & {$[$ na $] \sim[\mathrm{le}]$} & {$[\mathrm{ti}]$} \\
\hline & $(/ \mathrm{li} /)$ & $($ nya $\sim$ le $)$ & \\
\hline \multirow[t]{2}{*}{ water } & [se] & {$\left[\int w i\right]$} & [swi] \\
\hline & $(/ \mathrm{se} /)$ & (šui) & \\
\hline
\end{tabular}

a The marker appears to assimilate to the preceding noun or pronoun, e.g. yai-je 'my', $\eta$ - $\eta$ e 'your' etc. (e.g. Hashimoto 2010: 468).

b According to Hashimoto (2010: 451), there is no clusivity distinction in the Meixian dialect. However, Lau (2017) describes a distinction for the nearby Dabu 大埔 dialect, giving the first person plural inclusive form as $\varepsilon n(t \varepsilon u)$ and the first person plural exclusive as yai teu.

c $\operatorname{Lau}(2017)$.

A conspicuous feature of Timor Hakka is the relatively widespread use of the suffix-li, especially with names of animals, but also in other semantic domains; keu-li kjew-li 'dog', as in Table 2.3, is an example; (1) gives a few additional ones. This is reminiscent of the diminutive suffix -tsai as described by Lau (2017) for Hong Kong Hakka. 


$\begin{array}{llll}\text { ma-li } & \text { 'horse' } & k e-l i & \text { 'rabbit' } \\ \text { nu-li } & \text { 'cow' } & t 6 u-l i & \text { 'pig' } \\ \text { fa-li } & \text { 'flower' } & t \int^{h} a-l i & \text { 'car' } \\ \text { laj-li } & \text { 'man' } & m o j-l i & \text { 'woman' } \\ \text { to-li } & \text { 'knife' } & k o-l i & \text { 'song' }\end{array}$

Further study is necessary to determine whether the lexicon of Timor Hakka matches a particular Hakka dialect other than those shown in Table 2.3, or whether it combines mixed dialectal forms. A mix of dialectal features in Timor Hakka would point to koineization, and given the diverse linguistic makeup of immigrants as discussed above, it is likely that this process made at least some contribution to the emergence of Timor Hakka. A fact worth mentioning here is that my pilot fieldwork in Timor-Leste in 2017 with two speakers revealed noticeable heterogeneity in those language samples. The examples in Table 2.4 show that variation is found both in loanwords as well as Sinitic vocabulary; it concerns both content words as well as discourse markers, and there are both what appear to be pronunciation variants as well as etymologically unrelated lexemes. Speaker A is a man aged around 40, whose ancestors had come to Timor three or four generations ago and were likely Meixian Hakka. Speaker B is a man in his fifties, whose family has lived in Timor for 7 generations. He reports that his ancestors were brought to Timor from Macao as convicts.

Research into the factors determining these variants is yet to be carried out. In the meantime, a variety of factors can be hypothesized to be relevant. An important factor relates to the linguistic background of a speaker's family. For instance, the descendants of Cantonese convicts may have retained

TABLE 2.4 Lexical variation in Timor Hakka

\begin{tabular}{lll} 
English gloss & Speaker A & Speaker B \\
\hline bus & bas $(<$ English bus $)$ & masibombu $\left(<\right.$ Portuguese machimbombo $\left.{ }^{\text {a }}\right)$ \\
cat & mjan-kuy & meu-kuy \\
child & se-nin & se-kwei \\
enter & nip & nup \\
then; afterwards & jang-heu & kjak-mi
\end{tabular}

a According to Pons Online Portuguese-English dictionary (https://en.pons.com/translate/ portuguese-german/machimbombo\#dict), maximbombo 'bus' is characteristic of Angolan and Mozambique Portuguese. It is thought to be ultimately derived from the English phrase machine pump, a term used to refer to Lisbon's mechanic lifts (https://ciberduvidas.iscte-iul .pt/consultorio/perguntas/a-origem-da-palavra-machimbombo/24503). 
different linguistic features from descendants of Hakka-speaking immigrants; and the speech of those whose families originated in the Meixian area may show different dialectal features than that of other Hakka immigrants. It has also been shown in section 2 that linguistic background often correlates with other historical and demographic factors which are potentially relevant, that is the time of immigration and the likelihood of intermarriage with indigenous Timorese. The more recent the immigration event, the more likely a family's lect is to resemble the dialect of their mainland Chinese place of origin. On the other hand, the longer a family has lived in East Timor, the more likely it may be to see language contact effects. The majority of Chinese immigrants in the twentieth century were Meixian Hakka, while the descendants of Hokkien-speaking families have lived in East Timor for a considerably longer time. Cantonese speakers tended to be shunned by Hokkien and Hakka speakers and be of a lower socio-economic status. They were more likely to marry East Timorese women, and thus their descendants would have grown up in mixed households. This in turn may have resulted in a stronger linguistic influence of East Timorese languages. The same is true for families residing in rural areas, where often there were few other ethnic Chinese, or none at all. In Dili, on the other hand, there was a proper Chinese community and there may have been a stronger normative pressure acting on linguistic forms.

A further possible factor might be a speaker's age. East Timor's turbulent history is very directly reflected, for instance, in speakers' education. Older speakers who received the bulk of their education before 1975 would have gone either to a Portuguese or a Chinese school. As a result, Portuguese may be an obvious donor language for these speakers when it comes to linguistic borrowing. For those who went to school between 1975 and 2002, it would be Indonesian, as this was the sole language of education at the time. Finally, younger speakers, who received their formal education in Timor after independence in 2002, were educated in a mix of languages: the official languages at school have since then been Tetun and Portuguese. However, many teachers kept using Indonesian for a considerable time after independence due to the lack of Tetun-language teaching materials and their own insufficient fluency in Portuguese. Another factor related to an individual speaker's biography is whether he or she spent a considerable period abroad, and if so where. As mentioned, many Chinese-Timorese left Timor-Leste during the Indonesian rule, emigrating either to Australia, Macao, or Indonesian West Timor. Again, this had obvious consequences for their linguistic inventory and may influence their Hakka. A case in point are the two terms used in Timor Hakka for 'bus' as seen in Table 2.4: speaker A used the English loanword bas 'bus'. As an adolescent, he left Timor as a refugee and lived in Australia for several years. 
Speaker B, who did not share this background, used masibombu 'bus'. When asked about this term, speaker A acknowledged knowing it as "an old word for 'bus". Finally, it is also possible that a speaker's gender influences his or her Hakka variety, at least in middle-aged and older speakers: women of those age groups did not leave the house very often in their youths, whereas younger women enjoy considerably more freedom. As a consequence, middle-aged and older women may be less fluent in other languages than men of the same age.

Language contact and lexical borrowing have already briefly been mentioned, and it is obvious that language contact contributed to the unique character of Timor Hakka. Numerous loanwords are found from Portuguese, as in (2), but also from local languages (3). Given that I have a limited amount of data and have worked with only two speakers, it is difficult at this stage to distinguish between established borrowings (used widely throughout the speech community) and nonce borrowings, where an item from another language is spontaneously used by a bilingual speaker but may not occur in another instance or be used by other speakers. As an approximation, I have classified the items in (4) as nonce borrowings because the speakers who used them were readily able to come up with 'real Hakka' translations when I inquired. I treat the items in (2) and (3) as established borrowings because they were either used by both speakers or recognized by both speakers, and no Hakka equivalent was readily produced.

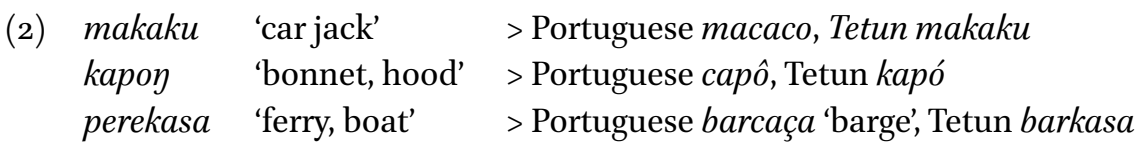

(3) pasat 'market'

kopi tf ${ }^{h} a$ 'coffee' (lit. 'coffee tea') > Indonesian kopi

kajko 'water spinach' > Tetun kanko kanku

(Ipomea aquatica)

kulu 'jackfruit' > Tetun kulu

(Artocarpus heterophyllus)

(4) niki 'bat' > Tetun niki

lutu 'fence' > Tetun lutu

maki 'angry' > Indonesian maki

23 This loan is found, in the same form, also in Indonesian, Malaysian and Singaporean Hakka. Thanks to Tom Hoogervorst for commenting on this. 
The linguistic character of Timor Hakka thus illustrates the point that the Sinophone "inevitably registers the multiple tongues spoken in constant interaction and creolization with indigenous and other local languages in a given place" (Shih 2013: 8-9). The preliminary insights on Timor Hakka in the preceding paragraphs have also shown how rudimentary our knowledge of this Hakka variety is. Much work thus remains to be done, and given the variety's endangered status, this is timely. The Hakka community of Timor-Leste as well as the expat community of Australia are well aware of the ongoing language loss and support efforts to document and describe their language.

\section{Concluding Remarks}

Ethnic Chinese people have been an established part of East Timor's scene for centuries. However, the Chinese-Timorese community has long been neglected in studies on Chinese-descended communities; only recently have a handful of publications on them appeared, most of which are historical in nature. It is one of the goals of this chapter to introduce the community to a wider readership within the context of Chinese-descended communities elsewhere in Southeast Asia.

The Chinese-Timorese were closely associated with the colonizers and have developed mixed cultural forms influenced by the long Portuguese rule. On the other hand, they have also lived side-by-side with the indigenous East Timorese largely peacefully, integrating into East Timorese society to varying degrees. Both in the colonial and post-independence periods, they have contributed significantly to building East Timor's economy and dominate the retail business until today. By the end of the colonial period in 1975, there was a small but thriving community of some 8,ooo people, making up around $1.5 \%$ of the total population (although estimates vary; see section 3.2). This situation was brought to an abrupt end by East Timor's declaration of independence and the subsequent Indonesian invasion, a pivotal event in Timor-Leste's recent history. It resulted in a 24-year occupation which brought much suffering not only to the Chinese-Timorese, but the whole population of East Timor.

At the very periphery of the Nanyang region, the Chinese-Timorese community originally arose as a satellite of the Chinese community of Kupang, West Timor. By the early twentieth century at the latest, when the colonial spheres of influence on Timor had fully consolidated, the Chinese residents of East Timor can be considered a "Luso-Chinese" community separate from the "Sino-Dutch" one of West Timor (Pinto 2014: 163). The circumstances of the ethnic Chinese in East Timor can be assumed to have differed from 
those in Netherlands Indies in a variety of respects. For instance, the long period spent under Portuguese colonial rule in East Timor left its mark in the form of both cultural and linguistic influences. It is known that East Timorese Chinese merchants had business relations with Chinese businessmen in ports in the Netherlands Indies such as Makassar and Surabaya as well as Singapore (Kammen \& Chen 2019: 83, fn. 4, 93). However, it is likely that they had to overcome a variety of administrative and political hurdles in order to maintain them, whereas ethnic Chinese residents of the Netherlands Indies would have faced few obstacles in conducting business with each other. On the other hand, Portuguese Timor had closer links to Macao than the ethnic Chinese in the Netherlands Indies had. Berlie (2015: 38) furthermore notes that, in contrast to Chinese-Indonesians, who speak a range of Sinitic languages, the Chinese-Timorese are exclusively Hakka-speaking. Given the difference in size between Indonesia and Timor-Leste, it is of course hardly surprising that the ethnic Chinese minority of Indonesia is much more diverse. We have also seen that the Hakka-speaking homogeneity of the Chinese-Timorese community is relatively recent. Another contrast that has been noted in the literature is that attitudes toward the Chinese in Indonesia have been characterized as a "mixture of resentment over riches and outright racism" (England 1999). In East Timor, there are no reports of anti-Chinese excesses by indigenous Timorese. While there is some resentment, several sources stress that the Chinese-Timorese are an accepted part of Timorese society.

On the other hand, Kiernan (2003) points out that the recent history of the Chinese-Timorese, which was shaped by the Indonesian invasion, parallels in a variety of respects that of the Chinese community of Cambodia, which is discussed in McFarland (this volume). In 1990, Kiernan wrote that " $[t]$ he Chinese under Pol Pot's regime suffered the worst disaster ever to befall any ethnic Chinese community in Southeast Asia" (Kiernan 1990). While the death toll among the Chinese-Timorese during the Indonesian invasion was lower, this event was probably equally disruptive. As a result of the events surrounding the Indonesian invasion, an estimated 4,00o Chinese-Timorese remain in Timor-Leste today, accounting for less than $0.4 \%$ of Timor-Leste's population. The majority of the community live in Australia. Wise (2006) as well as Chew \& Huang (2014) show that the Chinese-Timorese have a strong sense of identity and undertake significant efforts to maintain community relations, preferring to socialize with other Chinese-Timorese rather than with the wider Timorese or Chinese expat communities.

Language is an important part of many communities' identity. The ChineseTimorese speak a Hakka variety, which Wise (2006) confirms is a very significant identity marker for the expat community in Australia. Timor Hakka 
is now acutely endangered, both in Timor-Leste as well as in the Australian diaspora. My fieldwork in Timor-Leste has shown that speakers are aware of and concerned about this situation. To date, little is known about the linguistic characteristics of Timor Hakka. A preliminary lexical comparison suggests it is similar to the Meixian dialect of Hakka as described in Hashimoto (2010), although there are also lexical items that differ. Whether Timor Hakka aligns with another Hakka dialect from the Guangdong province, or whether it is a koine which evolved in Timor requires further research. First field data have furthermore shown that there appears to be a significant degree of variation within Timor-Hakka. The factors determining the occurrence of different variants are still unknown; one possibility is that they reflect differences between the varieties or languages of the original immigrants. Finally, the effects of contact with the other languages present in Timor, including the colonial language Portuguese as well as local languages and lingua francas, is obvious. However, not only Timor Hakka, but Southeast Asian Chinese varieties in general are to this day a largely untapped resource in Western linguistics, despite their obvious potential to inform scholarship in language contact, language attrition and maintenance, and sociolinguistics.

\section{References}

Babo Soares, Dionisio, 'Political developments leading to the referendum', in James J. Fox and Dionisio Babo Soares (eds.), Out of the Ashes: Destruction and Reconstruction of East Timor (Canberra: ANU E Press, 2003): 53-73. https://press.anu.edu.au/ publications/out-ashes.

Baxter, Alan N. and Hugo C. Cardoso, 'Early Notices Regarding Creole Portuguese in Former Portuguese Timor', Journal of Language Contact, 10/2 (2017): 264-317.

Berlie, Jean A., 'Chinese in East Timor: Identity, society and economy', HumaNetten, 35 (2015): 37-49.

Bonacich, Edna, 'A theory of middleman minorities', American Sociological Review, 38 (1973): 583-94.

CartoGIS Services, 'The position of Timor-Leste in relation to its closest neighbours', Canberra: College of Asia and the Pacific, The Australian National University (accessed 29 July 2019). http://asiapacific.anu.edu.au/mapsonline/.

Chappell, Hilary, 'Linguistic areas in China for differential object marking, passive, and comparative constructions', in Hilary Chappell (ed.), Diversity in Sinitic languages (Oxford: Oxford University Press, 2015): 13-52. 
Chappell, Hilary and Christine Lamarre, A Grammar and Lexicon of Hakka: Historical Materials from the Basel Mission Library (Paris: École des Hautes Études en Sciences Sociales, 2005).

Chew, Daniel and J. Sonia Huang, 'The Timorese Hakka in Australia: Community and the Internet', Global Hakka Studies, 2 (2014): 301-36.

Coates, Timothy J., 'The Portuguese Empire, 1100-1932', in Clare Anderson (ed.), A Global History of Convicts and Penal Colonies (London: Bloomsbury Academic, 2018): 27-64.

Constable, Nicole, 'Introduction: What does it mean to be Hakka?', in Nicole Constable (ed.), Guest People: Hakka Identity in China and Abroad (Seattle: University of Washington Press, 1996): 3-35.

Department of Immigration and Citizenship, Australian Government, Community Information Summary: Timor-Leste-born (Canberra: Community Relation Section, Department of Immigration and Citizenship, 2016) https://www.homeaffairs.gov.au/ about-us/our-portfolios/multicultural-affairs/community-information-summaries/ country-list-of-summaries.

Disney, Anthony R., A History of Portugal and the Portuguese Empire, vol. 1. (Cambridge: Cambridge University Press, 2009).

Douglas, Karen Manges and Rogelio Sáenz, 'Middleman Minorities', in William Darity (ed.), International Encyclopedia of the Social Sciences (2nd edn. Detroit, Mich.: The Gale Group, 2007): 147-48.

Dunn, James, Timor: A People Betrayed (Milton, Queensland: The Jacaranda Press, 1983).

Durand, Frédéric, 'Three centuries of violence and struggle in East Timor (1726-2008)', Online Encyclopedia of Mass Violence (2011). https://www.sciencespo.fr/mass-vio lence-war-massacre-resistance/en/document/three-centuries-violence-and-struggle -east-timor-1726-2008 (8 August, 2019).

Eberhard, David M., Gary F. Simons and Charles D. Fennig (eds.), Ethnologue: Languages of the World (22nd edn. Dallas, Texas: SIL International, 2019). http:// www.ethnologue.com.

Edwards, Owen and чвв, 'Languages of Timor', Kupang: Language \& Culture Unit (UвB) and Leiden University (2018). https://vici.marianklamer.org/linguistic-maps .html (26 July, 2019).

England, Vaudine, 'Chinese legacy of fear in Dili', South China Morning Post (1999). Hong Kong. https://etan.org/et9gb/september/1-4/1chinese.htm (6 August, 2019).

England, Vaudine, 'Catch a red taxi to downtown Dili', South China Morning Post. Hong Kong (2001). https://www.scmp.com/article/359255/catch-red-taxi-downtown-dili (6 August, 2019). 
Fat, Paul B. Tjon Sie, 'They Might as Well Be Speaking Chinese: The Changing Chinese Linguistic Situation in Suriname under New Migration', in Eithne B. Carlin, Isabelle Léglise, Bettina Migge and Paul B. Tjon Sie Fat (eds.), In and Out of Suriname: Language, Mobility and Identity (Leiden: Brill, 2015): 196-228.

Figueiredo, Fernando Augusto de, Timor: A presença portuguesa (1769-1945) (PhD thesis. Porto: Universidade de Porto, 2004).

Flynn, Dennis and Arturo Giraldez, 'Silk for Silver: Manila-Macao Trade in the 17th Century', Philippine Studies 44/1 (1996): 52-68.

General Directorate of Statistics. '2010 Census publications', 2010. http://www.statis tics.gov.tl/category/publications/census-publications/2010/ (12 September, 2019).

General Directorate of Statistics. '2015 Census publications', 2015. http://www.statis tics.gov.tl/category/publications/census-publications/2015-census-publications/ (12 September, 2019).

General Directorate of Statistics. Statistics Timor-Leste. http://www.statistics.gov.tl/ category/survey-indicators/timor-leste-in-figures/ (31 July, 2019).

Government of Timor-Leste. http://timor-leste.gov.tl/ (26 July, 2019).

Gunn, Geoffrey C., 'History of Timor', 1999. http://pascal.iseg.utl.pt/ cesa/History_of _Timor.pdf.

Gunn, Geoffrey C., 'The Timor-Macao Sandalwood Trade and the Asian Discovery of the Great South Land?', Review of Culture 53 (2016): 125-48.

Hägerdal, Hans, 'The Slaves of Timor: Life and Death on the Fringes of Early Colonial Society', Itinerario 34/2 (2010): 19-44. https://doi.org/10.1017/So165115310000331.

Hägerdal, Hans, Lords of the land, lords of the sea: Conflict and adaptation in early colonial Timor, 1600-1800 (Leiden: KITLV Press, 2012).

Hajek, John, 'Towards a language history of East Timor', Quaderni del Dipartimento di Linguistica-Università di Firenze 10 (2000): 213-27.

Hajek, John and Francesco Goglia, 'The East Timorese in Australia: Multilingual repertoires, language attitudes, practices and identity in the diaspora', Journal of Multilingual and Multicultural Development (2019): 1-18.

Hammarström, Harald, Robert Forkel and Martin Haspelmath, Glottolog 4.0 (Jena: Max Planck Institute for the Science of Human History, 2019). http://glottolog.org (31 July, 2019).

Hashimoto, Mantaro J., The Hakka dialect: A linguistic study of its phonology, syntax and lexicon (2nd edn., Cambridge: Cambridge University Press, 2010).

Heidhues, Mary Somers, 'Chinese settlements in rural Southeast Asia: Unwritten histories', in Anthony Reid and Kristine Alilunas-Rodgers (eds.), Sojourners and settlers: Histories of Southeast Asia and the Chinese (1996): 164-82. Honolulu: University of Hawai'i Press.

Hirth, Friedrich and W.W. Rockhill, Chau Ju-kua: his work on the Chinese and Arab trade in the twelfth and thirteenth centuries, entitled Chu-fan-chï (St Petersburg: Printing 
Office of the Imperial Academy of Sciences, 1911). https://archive.org/details/cu319 24023289345/page/ni/mode/2up (1 April, 2020).

Hull, Geoffrey, The Languages of East Timor: Some Basic Facts (Dili: Instituto Nacional de Linguística, Universidade Nacional Timor Lorosa'e, 2002).

Jannisa, Gudmund, Timor-Leste in the World: BC to Independence (Lund: A Malae Production, 2019).

Kammen, Douglas and Jonathan Chen, Cina Timor: Baba, Hakka, and Cantonese in the Making of Timor-Leste (New Haven: Yale University Southeast Asia Studies, 2019).

Kiernan, Ben, 'The Survival of Cambodia's Ethnic Minorities', Cultural Survival QuarterlyMagazine (1990). https://www.culturalsurvival.org/publications/culturalsurvival-quarterly/survival-cambodias-ethnic-minorities (31 October, 2019).

Kiernan, Ben, 'War, Genocide and Resistance in East Timor, 1975-99: Comparative Reflections on Cambodia', in Mark Seldon and Alvin Y. So (eds.), War and State Terrorism: The United States, Japan, and the Asia-Pacific in the Long Twentieth Century (Lanham, MD: Rowman \& Littlefield Publishers, 2003): 200-33.

KPP HAM, Investigative Commission into Human Rights Violations in East Timor, 'Full Report of the Investigative Commission into Human Rights Violations in East Timor', in Richard Tanter, Gerry van Klinken and Desmond Ball (eds.), Masters of Terror: Indonesia's Military and Violence in East Timor (Lanham: Rowman \& Littlefield Publishers, 2006): 21-66.

Kwartanada, Didi, 'Middlemen minority in an isolated outpost: A preliminary study of the Chinese in East Timor to 1945', 2001. Manuscript. Online at https://independent. academia.edu/DidiKwartanada (24.8.2018).

Lau, Chun Fat, 'Hakka Dialect', in Rint Sybesma (ed.), Encyclopedia of Chinese Language and Linguistics (Leiden: Brill, 2017): 469-83.

Lefort, Julie, 'Chinese languages spoken in Mauritius: An overview', 2018. https:// ro.uow.edu.au/mauritius5o/papers/1/7/.

Leong, Sow-Theng, Migration and Ethnicity in Chinese History: Hakkas, Pengmin and their Neighbours (Stanford: Stanford University Press, 1997).

Lombard-Jourdan, Anne and Claudine Salmon, 'Les Chinois de Kupang (Timor), aux alentours de 180o', Archipel 56/1 (1998): 393-428.

Luo, Xianglin, 客家研究導論 Introduction to Hakka Studies (Guangdong: Shishan Library, 1933).

Martin, Ian and Alexander Mayer-Rieckh, 'The United Nations and East Timor: From Self-Determination to State-Building, International Peacekeeping 12/1 (2005): 125-45.

Miao, Mu, Dandan Yin and Xinxin Zhang, 东帝汶: 帝力关帝庙 East Timor: Dili Guandi Temple, 2015. http://www.huaxia.com/zhsx/gggl/yw/2015/o8/4521464.html (27 April, 2020). 
Moutinho, Isabel, 'Exile at the Edges of Empire: Contemporary Writing in Portuguese', in Michael Hanne (ed.), Creativity in Exile (Amsterdam/New York: Rodopi, 2004): $71-86$.

Mulyanto, Randy, 'Chinese in East Timor: former Portuguese colony a model of integration by immigrants from China', South China Morning Post, 2019. https://www.scmp .com/lifestyle/family-relationships/article/3030631/chinese-east-timor-former -portuguese-colony-model (9 October, 2019).

Nicol, Bill, Timor: A Nation Reborn (Jakarta: Equinox Pub, 2002).

Norman, Jerry, Chinese (Cambridge: Cambridge University Press, 1988).

Norman, Jerry, 'The Chinese dialects: phonology', in Graham Thurgood and Randy J. LaPolla (eds.), The Sino-Tibetan languages (London: Routledge, 2003): 72-83.

Ooi, Keat Gin, 'Kapitan China System', in Keat Gin Ooi (ed.), Southeast Asia: A historical encyclopedia, from Angkor Wat to East Timor (Santa Barbara: Abc-Clio, 2004): 711.

Ormeling, Ferdinand Jan, The Timor Problem: A Geographical Interpretation of an Underdeveloped Island (Groningen: J.B. Wolters, 1956).

Pan, Lynn (ed.), The encyclopedia of the Chinese overseas (Singapore: Archipelago Press, 1998).

Pinto, Paulo Jorge de Sousa, 'Visitors and Settlers: Notes on Timor and the Chinese as Cultural and Economic Brokers (Sixteenth to Nineteenth Centuries)', Journal of Asian History 48/2 (2014): 139-64.

Pinto, Paulo Jorge de Sousa, 'Traders, middlemen, smugglers: The Chinese and the formation of colonial Timor (18th-19th centuries)', in José Vicente Serrão, Bárbara Direito, Eugénia Rodrigues and Susana Münch Miranda (eds.), Property Rights, Land and Territory in the European Overseas Empires (Lisbon: CEHC, ISCTEIUL, 2015): 267-77.

Ptak, Roderich, 'O transporte do sândalo para Macau e para a China durante a dinastia Ming', Revista de Cultura 1 (1987): 36-45.

Ptak, Roderich, 'Trade between Macau and Southeast Asia in Ming Times: A Survey', Monumenta Serica 54 (2006): 465-89.

Purcell, Victor, The Chinese in Southeast Asia (2nd edn., Oxford: Oxford University Press, 1966).

Rae, Ian and Morgen Witzel, The overseas Chinese of South East Asia: History, Culture, Business (Basingstoke: Palgrave Macmillan, 2008).

Raynor, Sophie, 'Timor-Leste's forgotten Chinese', South China Morning Post, 2019. http://lowyinstitute.com.au/the-interpreter/timor-leste-forgotten-chinese (6 August, 2019).

Sagart, Laurent, 'On distinguishing Hakka and non-Hakka dialects', Journal of Chinese linguistics (1998): 281-302. 
Sagart, Laurent and Hilary Chappell, 'Le hakka', in Emilio Bonvini, Joëlle Busuttil and Alain Peyraube (eds.), Encyclopédie des Sciences du Langage: Dictionnaire des langues (Paris: Presses Universitaire de France, 2011): 1016-24.

Scambary, James, 'Anatomy of a Conflict: The 2006-2007 Communal Violence in East Timor', Conflict, Security \& Development 9/2 (2009): 265-88.

Skinner, G. William, 'The Chinese Minority', in Ruth T. McVey (ed.), Indonesia (New Haven, Connecticut: Yale University, 1967): 97-117.

Soares, Laurentina "Mica” Barreto, 'Overseas Chinese, soft power and China's peopleto-people diplomacy in Timor-Leste', in Andrew McWilliam and Michael Leach (eds.), Routledge Handbook of Contemporary Timor-Leste (New York / London: Routledge, 2019): 314-30.

Sousa, Ivo Carneiro de, 'Para a História das relações entre Macau e Timor (séculos XVI-XX)', Revista de Cultura Edição Internacional, Macau 18 (2006): 13-22.

Subrahmanyam, Sanjay, Portuguese Empire in Asia, 1500-1700: A Political and Economic History (2nd edn., Hoboken: Wiley-Blackwell, 2012).

Tan, Chee-Beng (ed.), Routledge handbook of the Chinese diaspora (Oxon \& New York: Routledge, 2013).

Tan, Chee-Beng, Chinese Religion in Malaysia: Temples and Communities (Leiden: Brill, 2018).

Telkamp, Gerard J., 'De Ekonomische Struktuur van Portuguees-Timor in de Twintigste Eeuw: Een Voorlopige Schets', Amsterdam, unpublished manuscript, 1975.

Telkamp, Gerard J., 'The Economic Structure of an Outpost in the Outer Islands in the Indonesian Archipelago: Portuguese Timor 1850-1975', in Francien van Anrooij (ed.), Between People and Statistics: Essays on Modern Indonesian History Presented to P. Creutzberg (Dordrecht: Springer Netherlands, 1979): 71-89.

Thaler, Kai, 'Foreshadowing Future Slaughter: From the Indonesian Killings of 19651966 to the 1974-1999 Genocide in East Timor', Genocide Studies and Prevention, 7/2-3 (2012): 204-22.

The Heritage Foundation, '2019 Index of Economic Freedom', 2019. https://www.heri tage.org/index/country/timorleste (9 August, 2019).

Timor Tourism. 'The Chinese temple', Timor Tourism, 2015. https://web.archive.org/ web/20151125045647/http://timor-tourism.tl/poi/religious-building/dili/chinese -temple (8 October, 2019).

Treaty of Lisbon, 'Tratado de demarcação e troca de algumas possessões portuguesas e neerlandesas no arquipélago de Solor e Timor, entre sua majestade El-Rei de Portugal e sua majestade El-Rei dos Países Baixos, assinado em Lisboa pelos respectivos plenipotenciários aos 20 de Abril de 1859. Imprensa Nacional', 1861. https://books.google.ch/books?id=4gMMAAAAYAAJ\&printsec $=$ frontcover $\& d q=t r$ 
atado + de + lisboa + de $+1859 \&$ hl=pt-BR\&ei=3afNS_EFxPfwBq7PyWg\&sa=X\&oi=book _result\&ct=result\&redir_esc=y\#v=onepage\&q\&f=false (27 September, 2019).

Unesco Bangkok: Asia and Pacific Regional Bureau for Education, Overview of internal migration in Timor Leste, 2018. http://data.unescap.org/escap_stat/\#home (30 July, 2019).

United Nations, 'UNMIT: United Nations Mission in Timor-Leste', 2019. https://unmit .unmissions.org/ (9 August, 2019).

Wang, Gungwu, Don't leave home: Migration and the Chinese (Singapore: Eastern Universities Press, 2003).

Wise, Amanda, Exile and return among the East Timorese (Philadelphia: University of Pennsylvania Press, 2006).

Wurm, Stephen A., Rong Li and Theo Baumann, Language atlas of China (Australian Academy of the Humanities; Longman Group (Far East), 1987). 